\title{
Naturally Occurring Homoisoflavonoids and Their Pharmacological Activities
}

Authors

Affiliations
Li-Gen Lin ${ }^{1}$, Qian-Yu Liu ${ }^{1}$, Yang Ye ${ }^{2}$

${ }^{1}$ State Key Laboratory of Quality Research in Chinese Medicine, Institute of Chinese Medical Sciences, University of Macau, Macau, P. R. China

2 State Key Laboratory of Drug Research, Shanghai Institute of Materia Medica, Chinese Academy of Sciences, Shanghai, P. R. China
Key words

- homoisoflavonoids

phytochemistry

- biosynthesis

- pharmacological activities received March 14, 2014 revised July 31, 2014 accepted August 4, 2014

Bibliography

Dol http://dx.doi.org/

10.1055/s-0034-1383026

Published online August 25.

2014

Planta Med 2014; 80:

1053-1066 @ Georg Thieme

Verlag KG Stuttgart . New York . ISSN 0032-0943

\section{Correspondence}

\section{Dr. Li-Gen Lin}

State Key Laboratory of Quality

Research in Chinese Medicine

Institute of Chinese Medical

Sciences, University of Macau

Avenida da Universidade, Taipa

999078 Macau

P. R. China

Phone: +85388228041

ligenl@umac.mo

\section{Abstract}

$\nabla$

Homoisoflavonoids, a special subclass of flavonoids, are rarely found in nature, mainly existing in Fabaceae and Asparagaceae families and being less common in Polygonaceae, Portulacaceae, Orchidaceae, and Gentianaceae families. Until now, approximately 240 natural occurring homoisoflavonoids have been identified from roots, barks, heartwood, bulbs, leaves, and seeds of the plants from the above mentioned families, which have often been used in traditional medicine. Homoisoflavonoids have been reported with a broad range of bioactivities, including anti-microbial, anti-mutagenic, anti-oxidant, immunomodulatory, anti-diabetic, cytotoxic, anti-angiogenic, vasorelaxant, and anti-inflammatory effects. To organize this review, the homoisoflavonoids were classified into five groups based on their structures: sappanin-type (I), scillascillin-type (II), brazilin-type (III), caesalpin-type (IV), and protosappanin-type $(\mathrm{V})$. The structures of natural occurring homoisoflavonoids are described, and their proposed biosynthetic pathway and recent pharmacological studies are discussed. The main purpose of this review is to provide a comprehensive and up-to-date state of knowledge from phytochemical and pharmacological studies performed on homoisoflavonoids during the past decades. Homoisoflavonoids might have a large potential for further investigations of their bioactivities in order to identify important leads.

$\begin{array}{ll}\text { Abbreviations } \\ \nabla \\ \text { AAF: } & \text { acetylaminofluorene } \\ \text { Akt: } & \text { protein kinase B } \\ \text { AMPK: } & \begin{array}{l}\text { adenosine monophosphate-activated } \\ \text { protein kinase }\end{array} \\ \text { 2AN: } & \begin{array}{l}\text { 2-aminoanthracene } \\ \text { ATP: }\end{array}\end{array}$

BAPTA-AM: 1,2-bis(2-aminophenoxy)ethane-N,N, $\mathrm{N}^{\prime}, \mathrm{N}^{\prime}$-tetraacetic acid

Bcl-2: $\quad$ B-cell lymphoma 2

bFGF: basic fibroblast growth factor

BHA: butylated hydroxyanisole

BHT: butylated hydroxytoluene

CAM: chorioallantoic membrane

CD: $\quad$ circular dichroism

cGMP: $\quad$ cyclic guanosine 3',5'-monophosphate

c-src: proto-oncogene tyrosine-protein kinase sarcoma

CYP1A: cytochrome P4501A

DPPH: 2,2-diphenyl-1-picrylhydrazyl

ECD: electronic circular dichroism

EMS: ethyl methanesulfonate

EP: $\quad$ efflux pump

ERK1/2: extracellular regulated protein kinases $1 / 2$

F-2,6-BP: fructose-2,6-bisphosphate

F-6-P: $\quad$ fructose-6-phosphate

GLUT4: glucose transporter type 4

H-6-P: hexose-6-phosphate

HTS: high-throughput screening

$\mathrm{IC}_{50}$ : $\quad 50 \%$ inhibitory concentration

iNOS: inducible nitric oxide synthase

IL-2: $\quad$ interleukin 2

IL-4: $\quad$ interleukin 4

MIC: minimum inhibitory concentration

MMP-9: matrix metalloproteinase-9

L-NAME: N(G)-nitro-L-arginine methyl ester

L-NMMA: $\mathrm{N}(\mathrm{G})$-monomethyl-L-arginine acetate

LPS: lipopolysaccharide

NO: $\quad$ nitric oxide

NOS: $\quad$ nitric oxide synthase

ODQ: $\quad{ }^{1} \mathrm{H}-[1,2,4]$ oxadiazolo[4,3-a]quinoxalin-1-one

p21: $\quad$ cyclin-dependent kinase inhibitor 1

p53: tumor suppressor p53

PDGF: $\quad$ platelet-derived growth factor

PFK-2: $\quad$ 6-phosphofructo-2-kinase

PI3-kinase: phosphatidylinositol 3-kinase 
PPARY: peroxisome proliferator-activated receptor $\gamma$ PTKs: $\quad$ protein tyrosine kinases
ROS: $\quad$ reactive oxygen species

VSMC: vascular smooth muscle cell

\section{Introduction}

$\nabla$

Homoisoflavonoids are a rather uncommon subclass of flavonoids which contain one additional carbon atom. They mostly are likely to originate from chalcone precursors. Up to now, about 240 natural occurring homoisoflavonoids have been reported, distributed in various parts of plant materials. The homoisoflavonoids isolated so far could be classified into five types based on their carbon skeleton: sappanin-type (I), scillascillin-type (II), brazilin-type (III), caesalpin-type (IV), and protosappanin-type (V). Sappanin-type homoisoflavonoids are further subdivided according to the pyran ring moiety ( $\bullet$ Fig. 1 ).

Since a wide range of biological and medicinal activities are attributed to them, natural occurring homoisoflavonoids have been intensively studied in the past decades. In 2007, Abegaz et al. reviewed phytochemistry, biological activities, and synthesis of homoisoflavonoids, but they did not classify the structural types of homoisoflavonoids appropriately [1]. In the past seven years, more than 70 homoisoflavonoids have been isolated and structurally elucidated, and various new pharmacological activities related to homoisoflavonoids have been reported [2-36]. This review describes the structures of the homoisoflavonoids isolated so far, discusses the biosynthesis of their different structural types and also summarizes the biological activities of naturally occurring homoisoflavonoids.

\section{Occurrence of Homoisoflavonoids \\ $\nabla$}

Homoisoflavonoids are rarely found in nature, only existing in six families so far. The majority of homoisoflavonoids have been reported from Asparagaceae (Ophiopogon, Scilla, Muscari, Polygonatum, Liriope, Agave, Chlorophytum, Hyacintus, Pseudoprospero, Drimia, Ornithogalum, Ledebouria, Dracaena, Chionodoxa, Veltheimia, Bellevalia, Eucomis among others), and Fabaceae (Hoffmannseggia, Caesalpinia, Cassia, Pterocarpus, Haematoxylum among others). Few homoisoflavonoids have been found in Polygonaceae (Polygomum among others), Portulacaceae (Portulaca among others), Orchidaceae (Cremastra among others), and Gentianaceae (Tachiadenus among others) ( Table 1 to 6 ). Homoisoflavonoids are widely distributed in different parts of plants, including roots, barks, heartwood, bulbs, leaves, and seeds. The greatest number of homoisoflavonoids (44 compounds) has been isolated from Ophiopogon japonicus $[9,14,17$, $36-42$ ], and a notable number has also been identified in the heartwoods of Caesalpinia sappanin [6,7,15,18,24,31,34,4352]. All isoflavonoids are described based on their structural types.

\section{Structural Types of Homoisoflavonoids \\ $\nabla$}

Sappanin-type (I)

Sappanin-type homoisoflavonoids bear a 3-benzyl chromane skeleton, in which the benzopyran and aromatic rings are connected via one carbon. Until now, 191 sappanin-type homoisoflavonoids have been isolated and structurally elucidated. Based on the substitution on C-3 and C-4, and the location of the double bond in pyran ring, sappanin-type homoisoflavonoids could be further classified into six sub-groups: 3-benzylchroman type (Ia), 3-benzylchroman-3,4-diol type (Ib), 3-benzylchroman-4one type (Ic), 3-benzylchroman-3-ol-4-one type (Id), $\Delta^{2,3}$ 3-benzylchroman-4-one type (Ie), and $\Delta^{3,9}$ 3-benzylchroman-4-one type (If). Chemically, sappanin-type homoisoflavonoids can be easily cyclized and decyclized to form rearranged types, including scillascillin-type, brazilin-type, caesalpin-type, and protosappanin-type $[20,50]$. Additionally, the attachment of hydroxyl, methoxyl, formyl and methyl groups to the framework and the configurations of the carbons on the pyran ring contribute to structural diversity as well. Sappanin-type homoisoflavonoids account for a significant proportion of homoisoflavonoids.

3-benzylchroman type (Ia): Five 3-benzylchroman type homoisoflavonoids ([1-5], O Table 1) have been characterized from families Fabaceae (Caesalpinia and Haematoxylum) and Asparagaceae (Dracaena and Agave). The hydroxyl groups can be found on C-5 of ring $\mathrm{A}$ and $\mathrm{C}-4$ ' of ring $\mathrm{B}$. Compounds $\mathbf{1 - 3}$ were identified with a double bond at C-3 and C-4, while 4 and $\mathbf{5}$ were saturated at the same positions and the stereochemistry of C-3 remained unresolved. 3-benzylchroman type homoisoflavonoids are speculated to be byproducts of the biosynthesis of other molecules [20].

3-benzylchroman-3,4-diol type (Ib): This sub-group consists of eighteen compounds (6-23, O Table 1) that were identified from plants of the Fabaceae family (Caesalpinia and Haematoxylum). The hydroxy or methoxy moieties are located at C-4. The hydroxyl groups can be found on C-5 of ring A and C-4' of ring B. The hydroxyl group at $C-3$ is $\beta$-oriented in most compounds $[15,20,24$, $35,48,49$ ] and $\alpha$-oriented in only one compound (23) [15]. When the protons of the methylene (C-9) appear as singlet in the ${ }^{1} \mathrm{H}$-NMR spectrum, the relative configuration of the hydroxyl groups on C-3 and C-4 is determined as cis; on the contrary, when the methylene was shown as two doublets, the relative configuration of the hydroxyl groups could be trans $[15,20,24$, $35,48,49]$. The absolute configurations of C-3 and C- 4 were determined by $C D$ spectroscopy. The negative Cotton effect at $283 \mathrm{~nm}$ suggested absolute configurations of C-3 and C-4 to be $R$ and $S$, respectively; on the other hand, the positive Cotton effect at $283 \mathrm{~nm}$ indicated absolute configurations of C-3 and C-4 to be

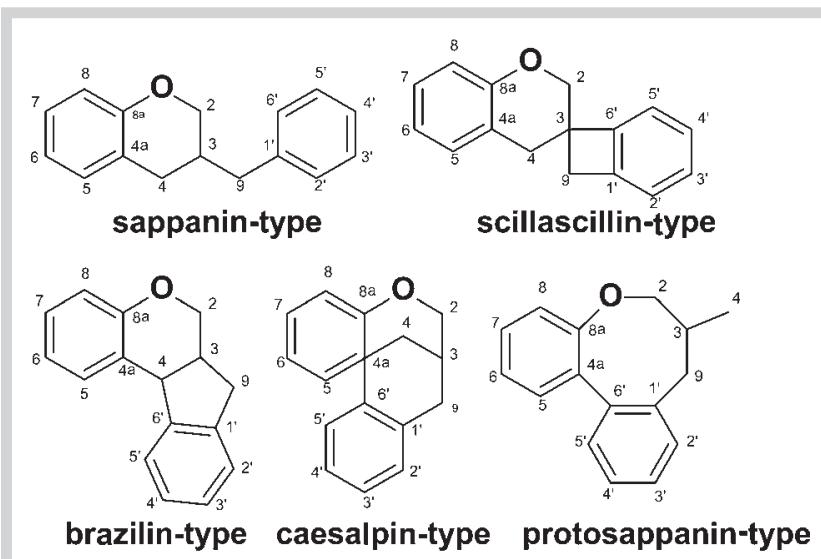

Fig. 1 Carbon skeletons of homoisoflavonoids. 
Table 1 Structures of 3-benzylchroman type (la) and 3-benzylchroman-3,4diol type (Ib) homoisoflavonoids, with their sources.

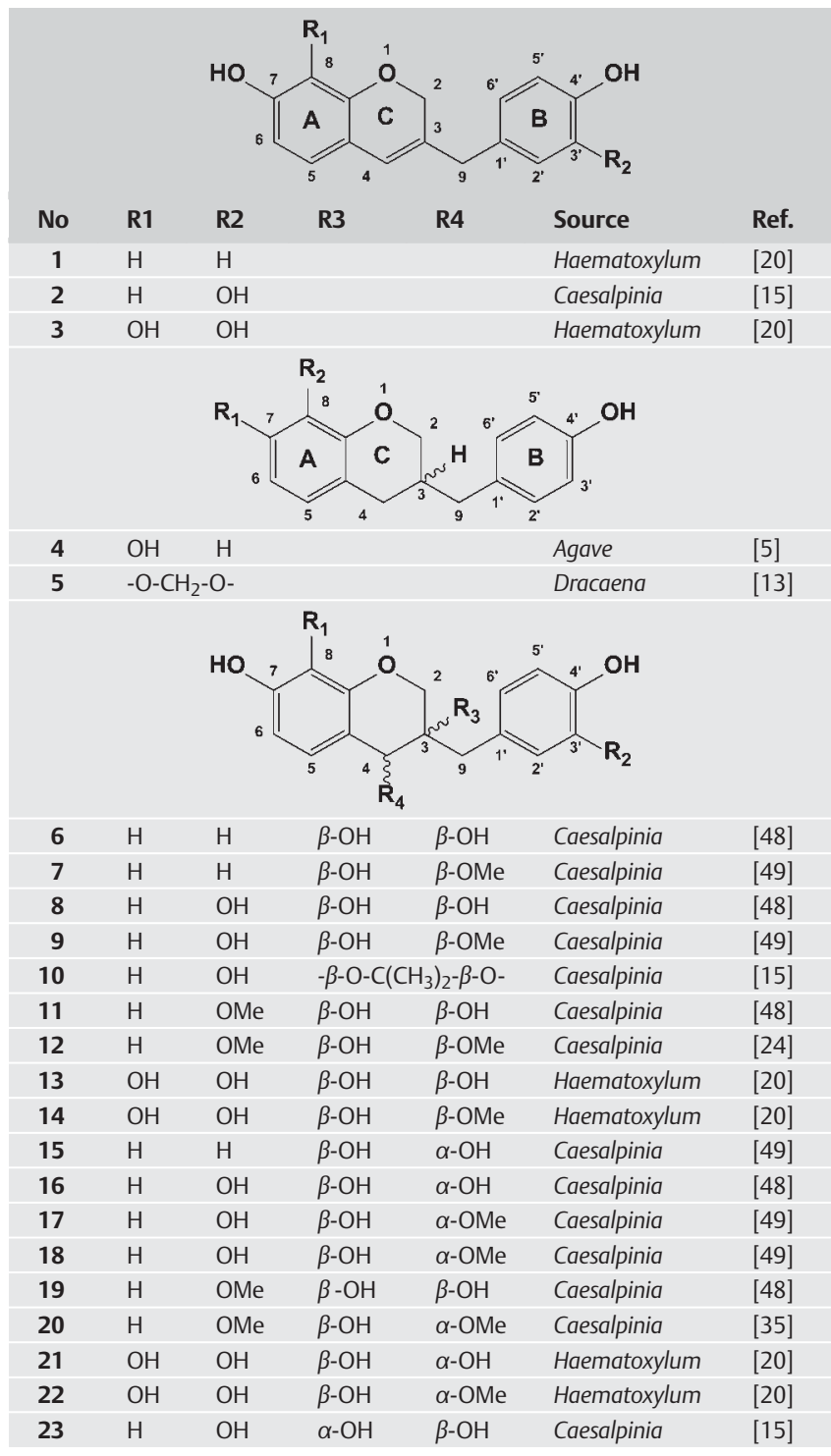

$R[20,49]$. Compound 10 from Caesalpinia sappan is unusual since it contains an acetonide moiety, therefore it could be speculated that it is an artificial derivative of compound 8 [15].

3-benzylchroman-4-one type (Ic): A large number of 3-benzylchroman-4-one type homoisoflavonoids have been reported. Till now, 88 compounds (24-111, 0 Table $\mathbf{2}$ ) were identified, from various medicinal plants, including several families: Fabaceae (Caesalpinia), Polygonaceae (Polygomum), Asparagaceae (Ophiopogon, Scilla, Muscari, Liriope Polygonatum, Agave, Drimia, Ledebouria, Chionodoxa, Bellevalia, and Eucomis), and Portulacaceae (Portulaca).

Of these, 49 compounds are only hydroxy-, methoxy-, acetyland/or methylenedioxy-substituted ( Table 2). Their great structural diversity is due to the number and position of these oxygen functions. Two to five oxygen-bearing moieties usually locate at C-6 and C-8 in ring A, as well as C- ${ }^{\prime}$ ' and C-4' in ring B, but rarely at other positions. Besides oxygen functions, other substituents can be found in 3-benzylchroman-4-one type homoisoflavonoids, such as methyl and formyl groups, which can be found at C-5 and C-7 of ring A. Compounds substituted with methyl and/or formyl groups have been only identified from the genera Ophiopogon and Liriope (Asparagaceae), as well as Polygonum (Polygonaceae). It could be considered as the chemical classification feature of these three genera.

The substitution of C-2 is uncommon in natural occurring homoisoflavonoids. Till now, there are only two such compounds with hydroxyl group at C-2 (110 and 121, OTable 2), isolated from Ophiopogon japonicus. The configuration of the hydroxyl group was not determined [37]. Recently, the first 9-hydroxylhomoisoflavone, polygohomoisoflavanone, (109, ○ Table 2) was isolated from Polygonum senegalense [23]. Homoisoflavonoids with isoprenoid-derived groups are rare; three such compounds (106108, $\odot$ Table 2) were isolated from Ledebouria floribunda [3].

The configuration of C-3 in 3-benzylchroman-4-one type homoisoflavonoids remained in the most cases unsolved. Recently, Dai et al determined the stereochemistry at C-3 by ECD spectroscopy. They found that a positive $\pi \rightarrow \pi^{*}$ Cotton effect in the $280-295 \mathrm{~nm}$ region and a negative $\mathrm{n} \rightarrow \pi^{*}$ Cotton effect in the $310-325 \mathrm{~nm}$ region indicated an $S$ configuration of this position [7].

3-benzylchroman-3-ol-4-one type (Id): This class is represented by 24 members (112-135, 0 Table 3), which have been identified from Fabaceae (Caesalpinia and Haematoxylum) and Asparagaceae (Ophiopogon, Polygonatum, Liriope, Agave, Dracaena, Ledebouria, Pseudoprospero, Hyacinthus, and Drimia) and are shown in $\odot$ Table 3. In addition, three $O$-glycosylated homoisoflavonoids (133-135) were isolated from Ornithogalum caudatum (Asparagaceae) [69]. These compounds carry a varying number of $O$-substituents on ring A and ring B, including hydroxyl, methoxyl, and methylenedioxyl groups ( $\bullet$ Table 3 ). These substituents are usually located at C-5, C-7, C-3,' and C-4', and only in some cases at C-6 and C-8. Beside those, a methyl group can be found at C-6. The hydroxyl group at C-3 can be $\alpha$ - or $\beta$-oriented. Using ECD spectroscopy, Dai et al. found a positive $\pi \rightarrow \pi^{*}$ Cotton effect in the $280-295 \mathrm{~nm}$ region and a negative $\mathrm{n} \rightarrow \pi^{*}$ Cotton effect in the $310-325 \mathrm{~nm}$ region indicating a $R$ configuration at C-3 [7].

$\Delta^{2,3} 3$-benzylchroman-4-one type (Ie): This group of homoisoflavonoids comprises currently twenty compounds ( $\bullet$ Table 4). Among them, nineteen compounds (137-155) were identified from the genus Ophiopogon (Asparagaceae), and only one (136) was isolated from the genus Cassia (Fabaceae) ( Table 4). They are all hydroxy-substituted at C-5 in ring A, and usually hydroxyl-, methoxy-, and/or methylenedioxy-substituted at C-7 in ring A, as well as at C-2', C-3', and C-4' in ring B. Additionally, methyl and/or formyl groups can be found at C-6 and C-8 in ring A in compounds isolated from the genus Ophiopogon. The only one with methyl group at C-7 was isolated from the genus Cassia, which was the first example with a methyl substituent from the Fabaceae family. Therefore, a re-authentication of the investigated plant material might be of interest.

$\Delta^{3,9}$ 3-benzylchroman-4-one type (If): This group consists of 36 compounds ( Table 5). Among them, most (156-186) have an E-geometry double bond at C-3 and C-9 (- Table 5). A varying number of $O$-substituents are present on rings $\mathrm{A}$ and $\mathrm{B}$, including hydroxyl, methoxyl, acetyl and/or methylenedioxyl functions. These groups are usually located at C-5, C-7, C-8, C-3', and C-4', but can be found in some cases also at C-6 and C-2'. Interestingly, the $\Delta^{3,9}$ 3-benzylchroman-4-one type homoisoflavonoids from Fabaceae (Caesalpinia and Hoffmannseggia) have no substitution at C-5. The others, isolated from Asparagaceae (Scilla, Muscari, Ledebouria, Hyacinthum, Chionodoxa, and Eucomis) and Portulacaceae (Portulaca) have 0 -substituents at $\mathrm{C}-5$. This difference might be considered as chemical classification feature. 
Table 2 Structures of 3-benzylchroman-4-one type (Ic) homoisoflavonoids, with their sources.

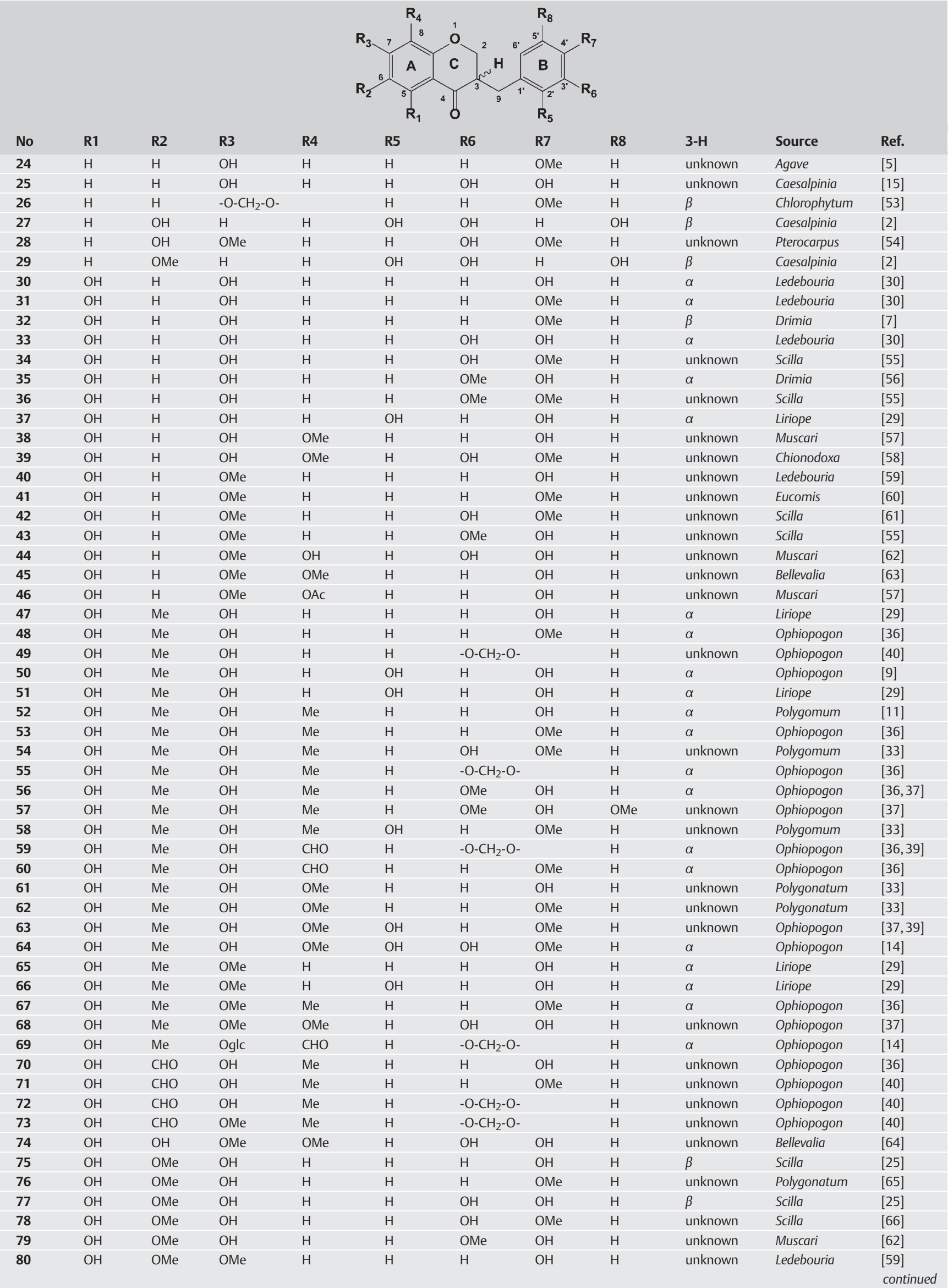


Table 2 Continued

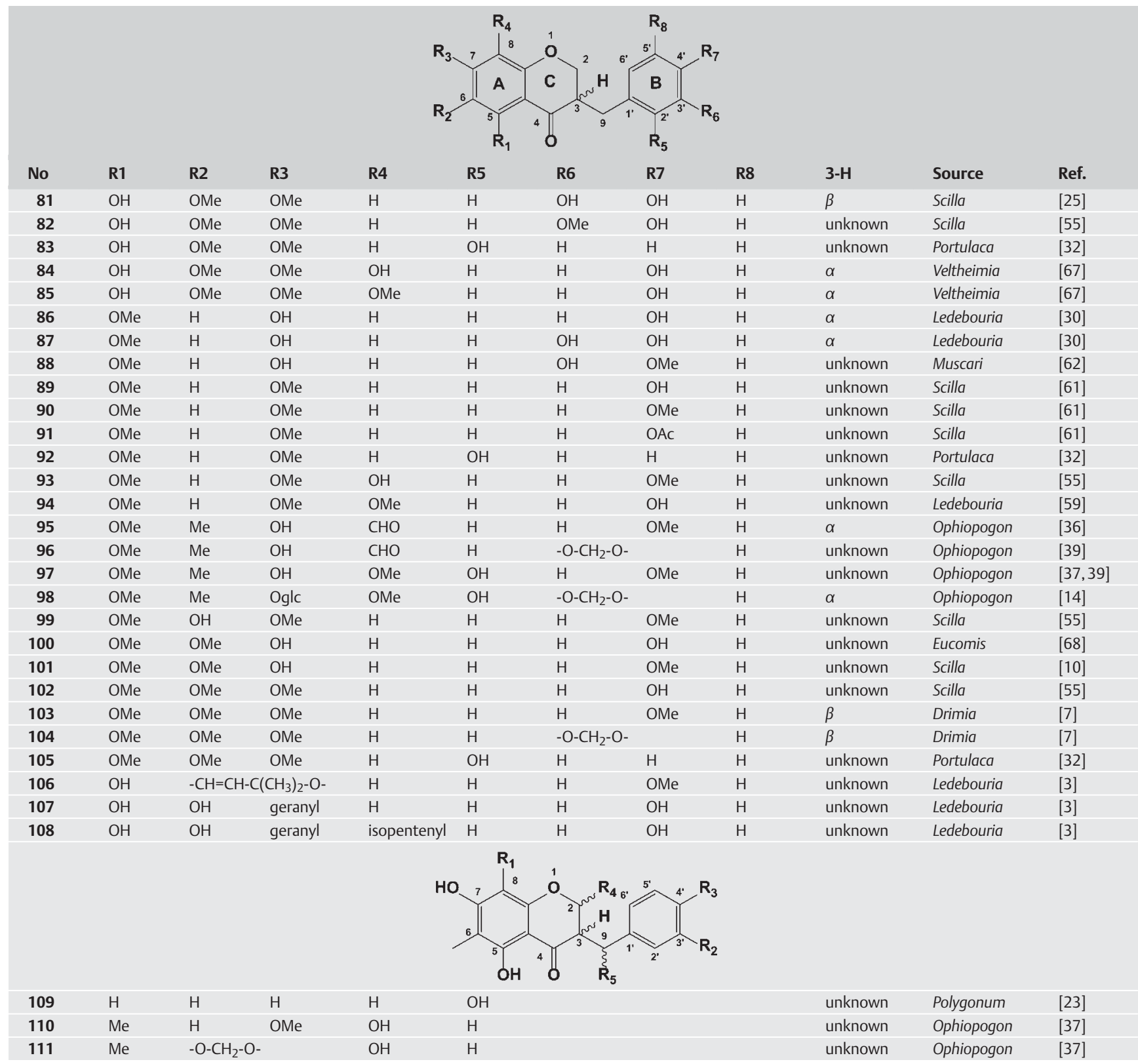

Homoisoflavonoids with Z-geometry double bond at C-3 and C-9 are rare; there are only five such compounds reported till now (187-191, O Table 5), isolated from genera Eucomis and Caesalpinia $[4,27,60,73]$. They are all methoxy-substituted at C-4' in ring $\mathrm{B}$, and usually hydroxyl- and/or methoxy-substituted at C-5, C-7, and $\mathrm{C}-8$ in ring $\mathrm{A}$. The $E$ - and $Z$-isomers can be easily distinguished by ${ }^{1} \mathrm{H}$-NMR-spectroscopy since the characteristic signals of $\mathrm{H}-2$ and $\mathrm{H}-9$ of the $\mathrm{Z}$-isomer appear as a singlet at about $5.00 \mathrm{ppm}$ and a broad singlet at $7.00 \mathrm{ppm}$, respectively, while those of the corresponding E-isomer appear as a doublet at about $5.40 \mathrm{ppm}$ and a broad singlet at $7.80 \mathrm{ppm}$, respectively $[8,27]$.

\section{Scillascillin-type (II)}

The C-6' in ring B of sappanin-type compounds connects to C-3 in pyran ring to form a spiro four-member ring, which is classified as scillascillin-type homoisoflavonoid. Until now, 16 scillascillintype homoisoflavonoids have been isolated and identified (192-
207, O Table 6). These compounds carry $O$-substituents at $\mathrm{C}-5$ and $\mathrm{C}-7$ in ring $\mathrm{A}$, and $\mathrm{C}-2^{\prime}, \mathrm{C}^{-} 3^{\prime}$, and $\mathrm{C}-4^{\prime}$ in ring $\mathrm{B}$, including hydroxyl, methoxyl, methylenedioxyl and acetyl functions. Scillascillin-type homoisoflavonoids were only isolated from Asparagaceae (Scilla, Muscari, Ledebouria, and Chionodoxa). The stereochemistry of C-3 is mostly unsolved. Using ECD spectroscopy, recent studies determined the stereochemistry at C-3 as $R$ by the positive $\pi \rightarrow \pi^{*}$ Cotton effect in the $290-300 \mathrm{~nm}$ region and the negative $\mathrm{n} \rightarrow \pi^{*}$ Cotton effect in the $330-350 \mathrm{~nm}$ region $[25,30]$.

\section{Brazilin-type (III)}

Brazilin-type homoisoflavonoids result when the C- 6 ' in ring B of sappanin-type compounds connects to $\mathrm{C}-4$ in the pyran ring to form a fused five-member ring. Only nine brazilin-type homoisoflavonoids have been reported from Fabaceae (Caesalpinia and Haematoxylum) so far (208-216, O Fig. 2) [20,24,48,49,81]. These compounds carry hydroxyl groups at C-7 in ring A and C- 
Table 3 Structures of 3-benzylchroman-3-ol-4-one type (Id) homoisoflavonoids, with their sources.

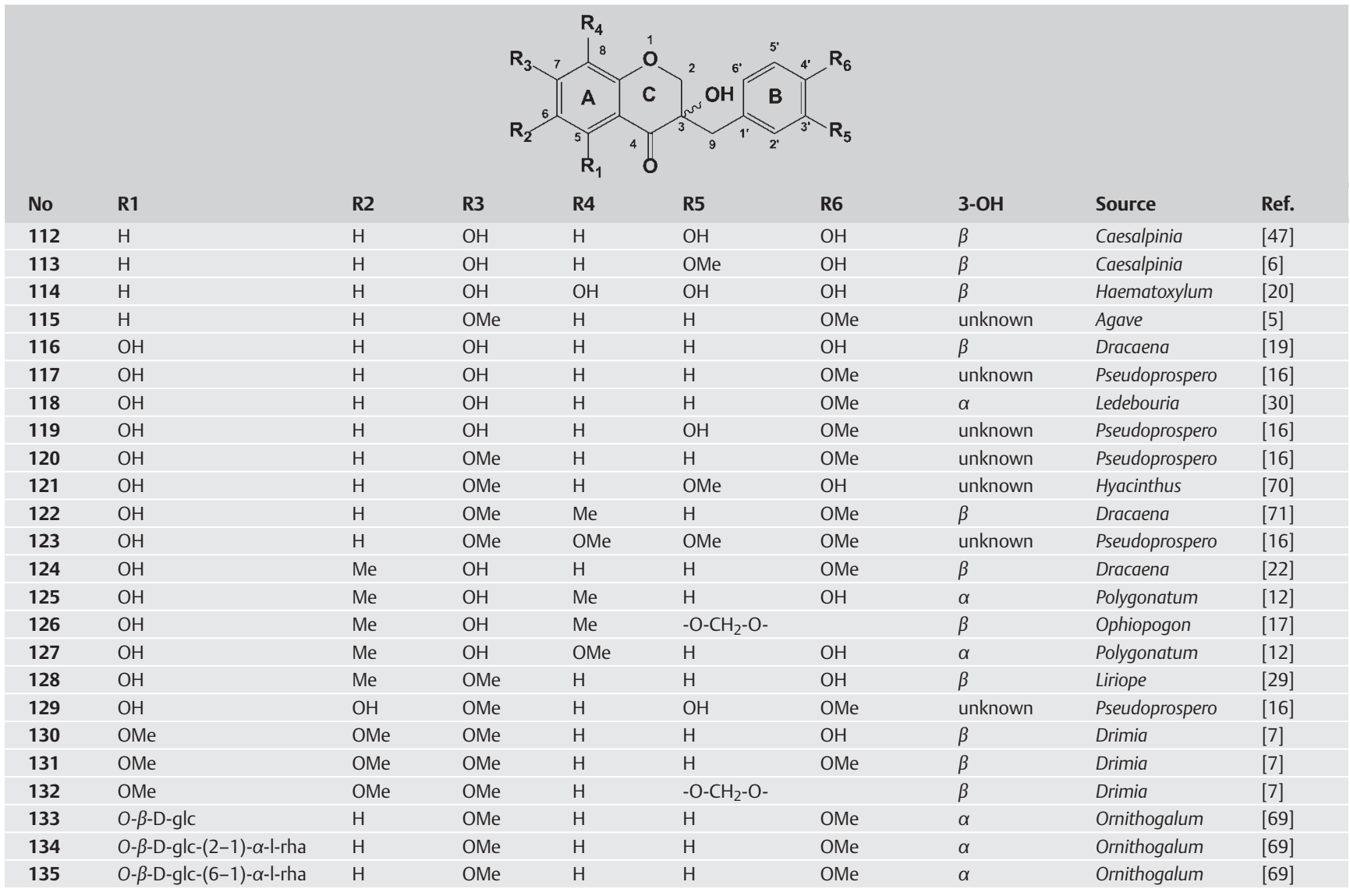

Table 4 Structures of $\Delta 2,3$ 3-benzylchroman-4-one type (le) homoisoflavonoids, with their sources.

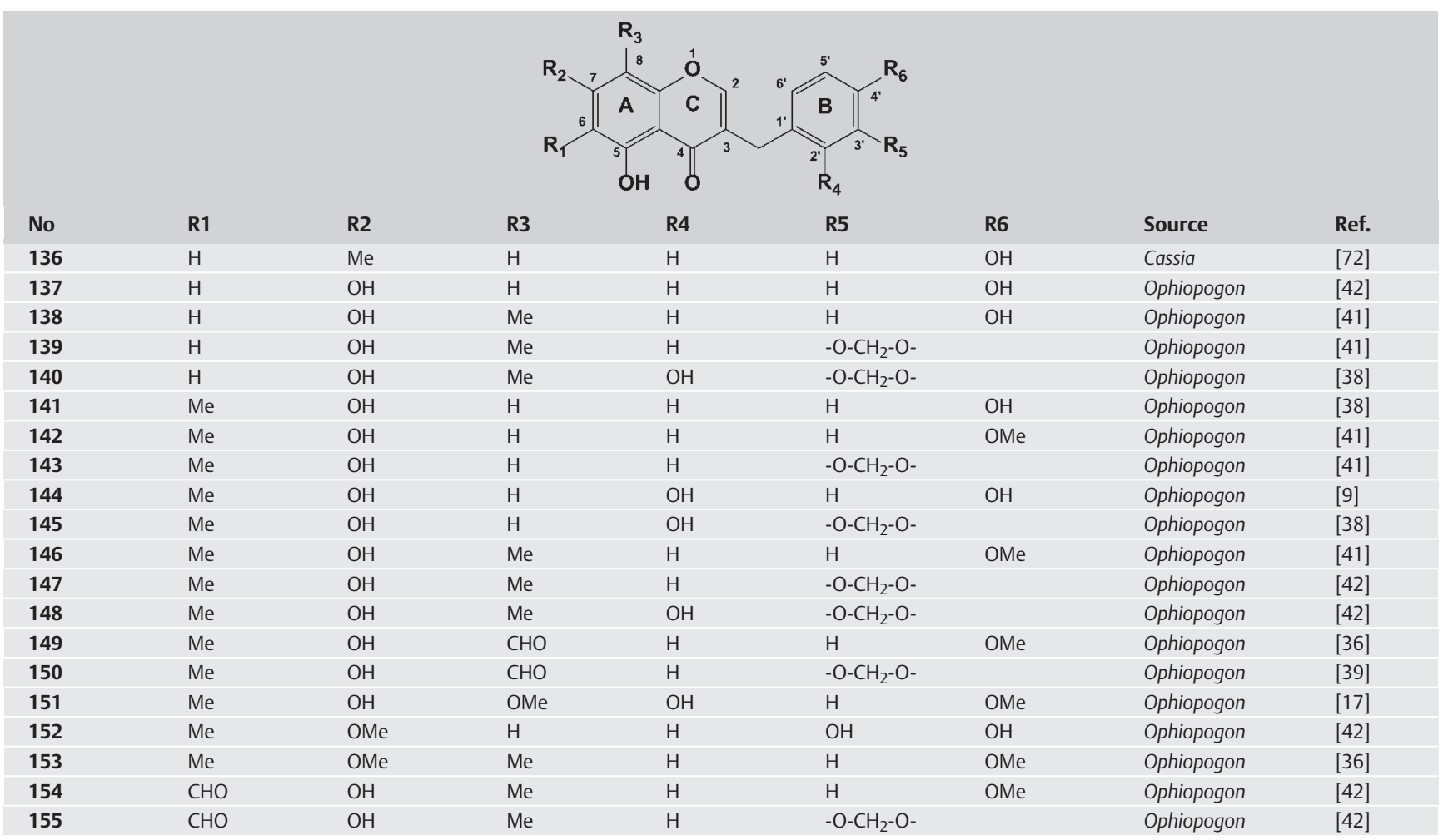


Table 5 Structures of $\Delta 3,9$ 3-benzylchroman-4-one type (If) homoisoflavonoids, with their sources.

\begin{tabular}{|c|c|c|c|c|c|c|c|c|c|}
\hline & & & & $\mathbf{R}_{4}$ & & & & & \\
\hline No & R1 & R2 & R3 & R4 & R5 & R6 & R7 & Source & Ref. \\
\hline 156 & $\mathrm{H}$ & $\mathrm{H}$ & $\mathrm{OH}$ & $\mathrm{H}$ & $\mathrm{H}$ & $\mathrm{H}$ & $\mathrm{OH}$ & Caesalpinia & [47] \\
\hline 157 & $\mathrm{H}$ & $\mathrm{H}$ & $\mathrm{OH}$ & $\mathrm{H}$ & $\mathrm{H}$ & $\mathrm{H}$ & Ome & Caesalpinia & [74] \\
\hline 158 & $\mathrm{H}$ & $\mathrm{H}$ & $\mathrm{OH}$ & $\mathrm{H}$ & $\mathrm{H}$ & $\mathrm{OH}$ & $\mathrm{OH}$ & Caesalpinia & [47] \\
\hline 159 & $\mathrm{H}$ & $\mathrm{H}$ & $\mathrm{OH}$ & $\mathrm{H}$ & $\mathrm{H}$ & $-\mathrm{O}-\mathrm{CH}_{2}-\mathrm{O}-$ & & Caesalpinia & {$[8]$} \\
\hline 160 & $\mathrm{H}$ & $\mathrm{H}$ & $\mathrm{OH}$ & $\mathrm{H}$ & $\mathrm{H}$ & $\mathrm{OH}$ & Ome & Caesalpinia & [8] \\
\hline 161 & $\mathrm{H}$ & $\mathrm{H}$ & $\mathrm{OH}$ & $\mathrm{OH}$ & $\mathrm{H}$ & $\mathrm{H}$ & OMe & Hoffmannseggia & [75] \\
\hline 162 & $\mathrm{H}$ & $\mathrm{H}$ & $\mathrm{OH}$ & $\mathrm{OMe}$ & $\mathrm{H}$ & $\mathrm{H}$ & OMe & Caesalpinia & [27] \\
\hline 163 & $\mathrm{H}$ & $\mathrm{H}$ & OMe & $\mathrm{H}$ & $\mathrm{H}$ & $\mathrm{H}$ & $\mathrm{OH}$ & Caesalpinia & [76] \\
\hline 164 & $\mathrm{H}$ & $\mathrm{H}$ & OMe & $\mathrm{H}$ & $\mathrm{H}$ & $\mathrm{H}$ & OMe & Caesalpinia & [8] \\
\hline 165 & $\mathrm{H}$ & $\mathrm{H}$ & OMe & $\mathrm{H}$ & $\mathrm{H}$ & OMe & OMe & Caesalpinia & [8] \\
\hline 166 & $\mathrm{H}$ & $\mathrm{H}$ & $\mathrm{OMe}$ & $\mathrm{H}$ & $\mathrm{H}$ & $-\mathrm{O}-\mathrm{CH}_{2}-\mathrm{O}-$ & & Caesalpinia & {$[8]$} \\
\hline 167 & $\mathrm{H}$ & $\mathrm{H}$ & OMe & $\mathrm{OH}$ & $\mathrm{H}$ & $\mathrm{H}$ & OMe & Hoffmannseggia & [75] \\
\hline 168 & $\mathrm{H}$ & $\mathrm{H}$ & OMe & OMe & $\mathrm{H}$ & $\mathrm{H}$ & $\mathrm{OH}$ & Caesalpinia & [76] \\
\hline 169 & $\mathrm{H}$ & $\mathrm{Me}$ & $\mathrm{H}$ & $\mathrm{Me}$ & $\mathrm{H}$ & $\mathrm{H}$ & $\mathrm{OH}$ & Polygonatum & [33] \\
\hline 170 & $\mathrm{H}$ & OMe & OMe & $\mathrm{H}$ & $\mathrm{H}$ & $\mathrm{OH}$ & OMe & Caesalpinia & [8] \\
\hline 171 & $\mathrm{OH}$ & $\mathrm{H}$ & $\mathrm{OH}$ & $\mathrm{H}$ & $\mathrm{H}$ & $\mathrm{H}$ & $\mathrm{OH}$ & Scilla & [55] \\
\hline 172 & $\mathrm{OH}$ & $\mathrm{H}$ & $\mathrm{OH}$ & $\mathrm{H}$ & $\mathrm{H}$ & $\mathrm{H}$ & OMe & Eucomis & [60] \\
\hline 173 & $\mathrm{OH}$ & $\mathrm{H}$ & $\mathrm{OH}$ & OMe & $\mathrm{H}$ & $\mathrm{H}$ & $\mathrm{OH}$ & Chionodoxa & [58] \\
\hline 174 & $\mathrm{OH}$ & $\mathrm{H}$ & $\mathrm{OH}$ & OMe & $\mathrm{H}$ & $\mathrm{H}$ & OMe & Eucomis & [77] \\
\hline 175 & $\mathrm{OH}$ & $\mathrm{H}$ & $\mathrm{OH}$ & OMe & $\mathrm{H}$ & $\mathrm{OH}$ & $\mathrm{OH}$ & Chionodoxa & [58] \\
\hline 176 & $\mathrm{OH}$ & $\mathrm{H}$ & OMe & $\mathrm{H}$ & $\mathrm{H}$ & $\mathrm{H}$ & $\mathrm{OH}$ & Scilla & [55] \\
\hline 177 & $\mathrm{OH}$ & $\mathrm{H}$ & OMe & $\mathrm{H}$ & $\mathrm{H}$ & $\mathrm{H}$ & OMe & Eucomis & [60] \\
\hline 178 & $\mathrm{OH}$ & $\mathrm{H}$ & OMe & $\mathrm{H}$ & $\mathrm{OH}$ & $\mathrm{H}$ & $\mathrm{H}$ & Portulaca & [32] \\
\hline 179 & $\mathrm{OH}$ & $\mathrm{H}$ & OMe & $\mathrm{OH}$ & $\mathrm{H}$ & $\mathrm{OH}$ & $\mathrm{OH}$ & Muscari & [78] \\
\hline 180 & $\mathrm{OH}$ & $\mathrm{H}$ & Oglc & $\mathrm{H}$ & $\mathrm{H}$ & $\mathrm{H}$ & $\mathrm{OH}$ & Polygonatum & [33] \\
\hline 181 & $\mathrm{OH}$ & $\mathrm{OH}$ & $\mathrm{OH}$ & OMe & $\mathrm{H}$ & $\mathrm{H}$ & $\mathrm{OH}$ & Hyacinthum & [70] \\
\hline 182 & $\mathrm{OH}$ & OMe & $\mathrm{OH}$ & $\mathrm{H}$ & $\mathrm{H}$ & $\mathrm{H}$ & $\mathrm{OH}$ & Eucomis & [77] \\
\hline 183 & $\mathrm{OH}$ & OMe & $\mathrm{OH}$ & $\mathrm{H}$ & $\mathrm{H}$ & $\mathrm{H}$ & OMe & Scilla & [55] \\
\hline 184 & $\mathrm{OH}$ & OMe & $\mathrm{OH}$ & $\mathrm{H}$ & $\mathrm{H}$ & $\mathrm{OH}$ & $\mathrm{OH}$ & Scilla & [55] \\
\hline 185 & $\mathrm{OMe}$ & $\mathrm{H}$ & $\mathrm{OH}$ & $\mathrm{H}$ & $\mathrm{H}$ & $\mathrm{OH}$ & $\mathrm{OH}$ & Muscari & [78] \\
\hline 186 & $\mathrm{OAC}$ & $\mathrm{H}$ & $\mathrm{OH}$ & $\mathrm{H}$ & $\mathrm{H}$ & $\mathrm{OH}$ & $\mathrm{OH}$ & Ledebouria & [30] \\
\hline & & & & & & & & & \\
\hline 187 & $\mathrm{H}$ & $\mathrm{OH}$ & $\mathrm{H}$ & & & & & Caesalpinia & [73] \\
\hline 188 & $\mathrm{H}$ & $\mathrm{OH}$ & $\mathrm{OH}$ & & & & & Caesalpinia & [27] \\
\hline 189 & $\mathrm{H}$ & $\mathrm{OH}$ & OMe & & & & & Caesalpinia & [4] \\
\hline 190 & $\mathrm{OH}$ & $\mathrm{OH}$ & $\mathrm{H}$ & & & & & Eucomis & [60] \\
\hline 191 & $\mathrm{OH}$ & OMe & $\mathrm{H}$ & & & & & Eucomis & [60] \\
\hline
\end{tabular}

$4^{\prime}$ in ring B. Brazilin (208) and hematoxylin (213) were isolated as the major constituents of the heartwood of Caesalpinia sappan and Haematoxylum campechianum, respectively [20,49]. Hematoxylin (213) was identified to be the sweet principle of the heartwood of $H$. campechianum, while brazilin (208) and hematein (216) are tasteless [81].

\section{Caesalpin-type (IV)}

The C-6' in ring B of sappanin-type compounds connects to C-4a of the pyran ring to form a bridged six-member ring in caesalpintype homoisoflavonoids. Only seven caesalpin-type homoisoflavonoids have been reported from families Fabaceae (Caesalpinia and Haematoxylum) and Asparagaceae (Dracaena) so far (217223, Fig. 3) $[20,35,51,82]$. The compounds carry a carbonyl group at C-7 in ring $\mathrm{A}$ and are usually hydroxyl-substituted at $\mathrm{C}$ $3^{\prime}$ and $C-4$ ' in ring $B$. When the hydroxyl group at $C-3$ is $\beta$-orient- 
Table 6 Structures of scillascillin-type (II) homoisoflavonoids, with their sources.

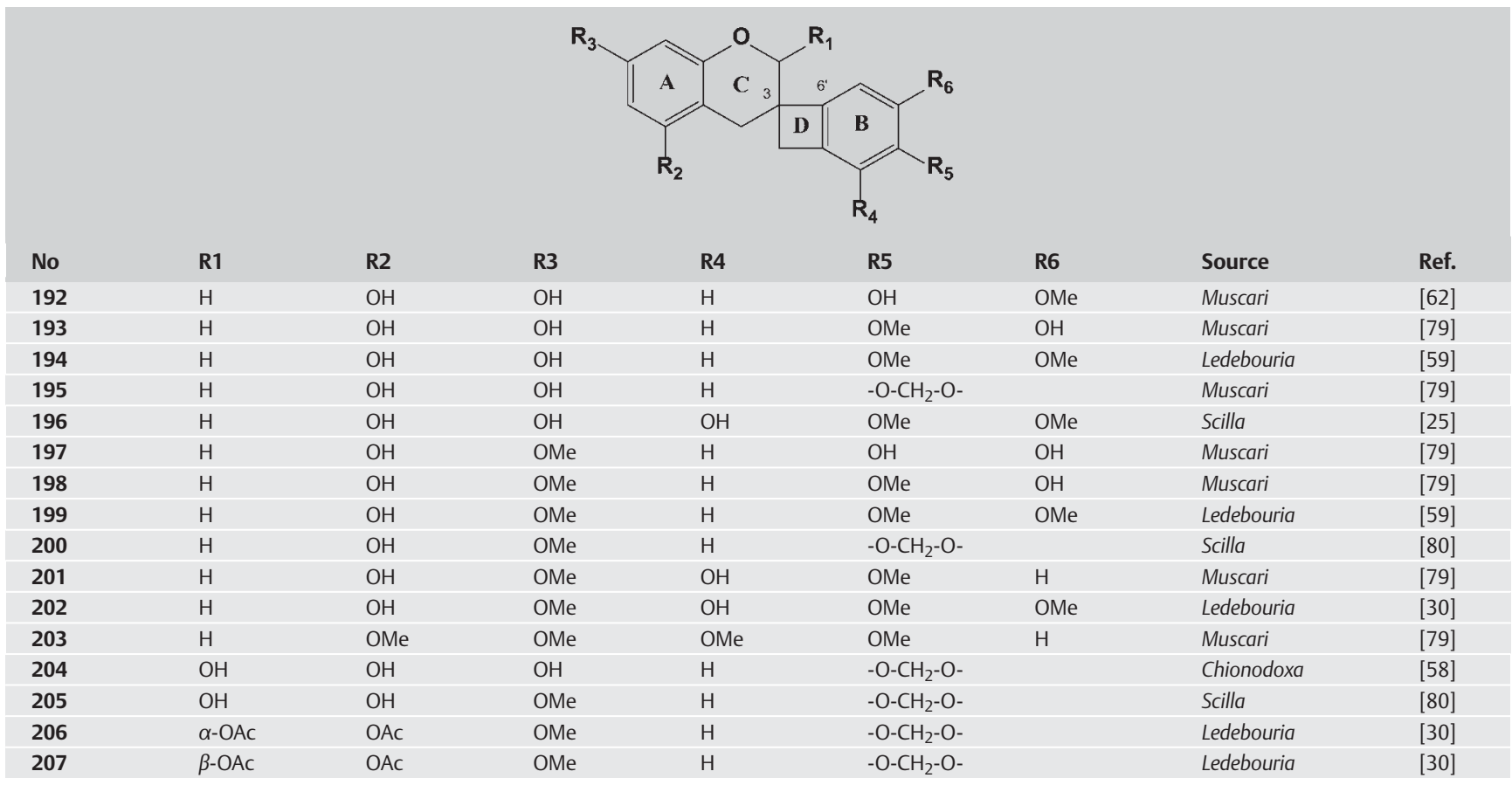

HO<smiles>[R]c1cc2c(c([R])c1[R])CC1([R])COc3ccccc3[C@H]21</smiles><smiles>[R]c1cc2c(c([R])c1O)[C@]1(C)COc3c(ccc(O)c3O)C[C@]2(O)C1</smiles>

HO<smiles>CC1C=CC2=C3C=C(O)C(=O)C=C3C(C)(O)COC2=C1</smiles>

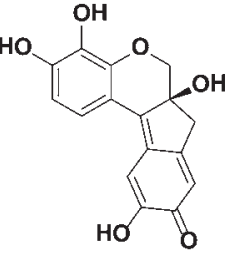

216
Fig. 2 Structures of brazilin-type (III) homoisoflavonoids.

208: $\mathrm{R} 1=\mathrm{OH} ; \mathrm{R} 2=\mathrm{H} ; \mathrm{R} 3=\mathrm{OH} ; \mathrm{R} 4=\mathrm{OH} \quad$ 213: R1 $=\mathrm{OH} ; \mathrm{R} 2=\mathrm{H}$ 209: $\mathrm{R} 1=\mathrm{OH} ; \mathrm{R} 2=\mathrm{OH} ; \mathrm{R} 3=\mathrm{OH} ; \mathrm{R} 4=\mathrm{H} \quad 214: \mathrm{R} 1=\mathrm{H} ; \mathrm{R} 2=\mathrm{OH}$

215

210: $\mathrm{R} 1=\mathrm{OH} ; \mathrm{R} 2=\mathrm{H} ; \mathrm{R} 3=\mathrm{OH} ; \mathrm{R} 4=\mathrm{OMe}$

211: $\mathrm{R} 1=\mathrm{OH} ; \mathrm{R} 2=\mathrm{H} ; \mathrm{R} 3=\mathrm{OMe} ; \mathrm{R} 4=\mathrm{OH}$

212: $\mathrm{R} 1=\mathrm{H} ; \mathrm{R} 2=\mathrm{H} ; \mathrm{R} 3=\mathrm{OH} ; \mathrm{R} 4=\mathrm{OH}$

ed, the relative configuration of C- 4 can be determined by signal appearance of $\mathrm{H}-9$ in ${ }^{1} \mathrm{H}-\mathrm{NMR}$ spectrum. When $\mathrm{H}-9$ appears as a doublet, the methoxyl group at C-3 is $\beta$-oriented; when $\mathrm{H}-9$ appears as two doublets, the methoxyl group is $\alpha$-oriented $[20,35]$.

\section{Protosappanin-type (V)}

When the single bond between C-4 and C-4a participates in the formation of an eight-member ring, the resulting homoisoflavonoids are classified as protosappanin-type. Eleven compounds have been reported (224-234, - Fig. 4) so far, isolated only from Fabaceae (Caesalpinia and Haematoxylum) [6,20,21,31,43,46]. These compounds carry hydroxyl groups at C-7 in ring A and C$4^{\prime}$ in ring $\mathrm{B}$, and an $\mathrm{O}$-substituent (hydroxyl or methoxyl) at $\mathrm{C}-3^{\prime}$ in ring $\mathrm{B}$. The substituents at C-3 could be hydroxyl, formyl, hydroxylmethyl, and carbonyl groups. Recently, the first eightmember ring opened protosappanin-type compound (234) was identified [31].

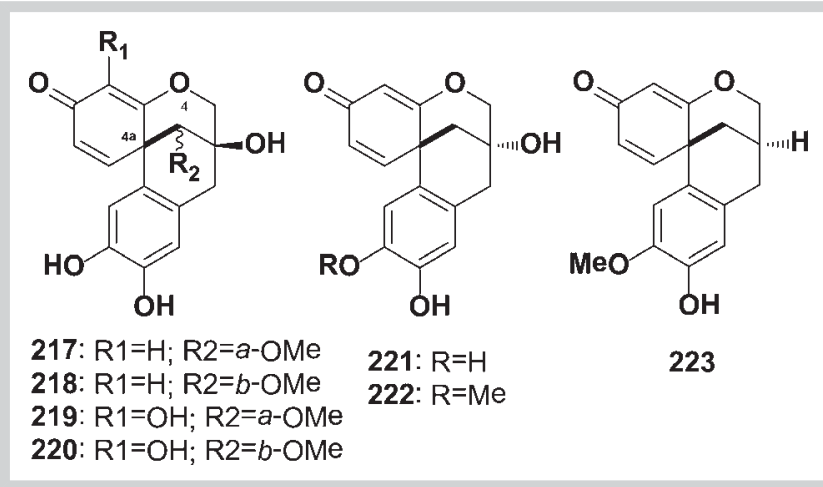

Fig. 3 Structures of caesalpin-type (IV) homoisoflavonoids. 


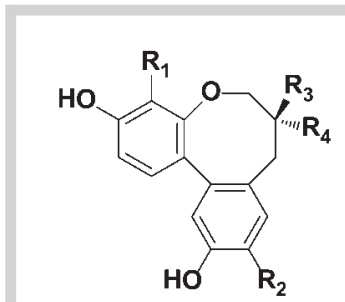

224: $\mathrm{R} 1=\mathrm{H} ; \mathrm{R} 2=\mathrm{OH} ; \mathrm{R} 3, \mathrm{R} 4=\mathrm{O}$

225: $\mathrm{R} 1=\mathrm{OH} ; \mathrm{R} 2=\mathrm{OH} ; \mathrm{R} 3, \mathrm{R} 4=\mathrm{O}$

226: $\mathrm{R} 1=\mathrm{H} ; \mathrm{R} 2=\mathrm{OH} ; \mathrm{R} 3=\mathrm{CHO} ; \mathrm{R} 4=\mathrm{OH}$

227: R1=H; R2=OH; R3 $=\mathrm{CH}_{2} \mathrm{OH} ; \mathrm{R} 4=\mathrm{OH}$

228: $\mathrm{R} 1=\mathrm{H} ; \mathrm{R} 2=\mathrm{OH} ; \mathrm{R} 3=\mathrm{Me} ; \mathrm{R} 4=\mathrm{OMe}$

229: $\mathrm{R} 1=\mathrm{OH} ; \mathrm{R} 2=\mathrm{OH} ; \mathrm{R} 3=\mathrm{CH}_{2} \mathrm{OH} ; \mathrm{R} 4=\mathrm{OH}$

230: R1 $=\mathrm{OH} ; \mathrm{R} 2=\mathrm{OMe} ; \mathrm{R} 3=\mathrm{CH}_{2} \mathrm{OH} ; \mathrm{R} 4=\mathrm{OH}$

231: R1 $=\mathrm{OH}$; R2 $=\mathrm{OH}$; R3 $=\mathrm{OH}$; $\mathrm{R} 4=\mathrm{CH}_{2} \mathrm{OH}$

232: $\mathrm{R} 1=\mathrm{OH} ; \mathrm{R} 2=\mathrm{OMe} ; \mathrm{R} 3=\mathrm{OH} ; \mathrm{R} 4=\mathrm{CH}_{2} \mathrm{OH}$<smiles>O=C1CCOc2cc(O)ccc2-c2cc(O)c(O)cc21</smiles>

233

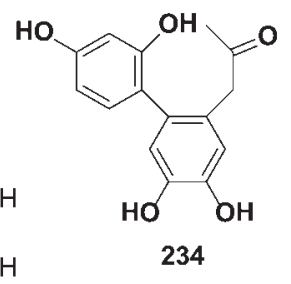

Fig. 4 Structures of protosappanin-type (V) homoisoflavonoids.

\section{Miscellaneous structures}

In addition, two condensation products of brazilin and protosappanin (235 and 236), a dimer of caesalpin-type compound (237), and three derivatives, brazilide A (238), caesalpin P (239), and caesalpiniaphenol B (240) were isolated from Caesalpinia sappan (๑ Fig. 5) $[6,44,51,52,83]$.

\section{Proposed Biosynthetic Pathway of Homoisoflavonoids $\nabla$}

Chalcones are considered as the precursors of homoisoflavonoids in their biosynthesis $[20,50]$. As shown in 0 Fig. $\mathbf{6}$, the chalcone precursor 2'-hydroxyl chalcone could be converted into a 3-benzylchroman-4-one type homoisoflavonoid, which in turn could be a 3-benzylchroman-3-ol-4-one type. The latter compounds could be reduced to a 3-benzylchroman type, 3-benzylchroman3,4-diol type, $\Delta^{2,3} 3$-benzylchroman-4-one type, and $\Delta^{3,9} 3$-benzylchroman-4-one type homoisoflavonoid, respectively. In addition, a 3-benzylchroman-4-one type homoisoflavonoid could cyclize to form a scillascillin-type, brazilin-type, or caesalpin-type compound, while the latter could further decyclize to form a protosappanin-type. For instance, all isolated homoisoflavonoids from Haematoxylum campechianum could be considered as precursors or byproducts of hematoxylin [20]. Through aldol condensation, dehydration, oxidation, and reduction, the chalcone precursor was finally transformed to the end product, hematoxylin. In this course, many homoisoflavonoids could be obtained as byproducts. The C-4 carbonyl group in 3-benzylchroman-4one type homoisoflavonoids would be non-selectively reduced to a hydroxyl group that could be methylated. Cyclization between C-4a and C-6' by a nucleophilic addition would result in caesalpin-type compounds. Further oxidation of caesalpin-type compounds could yield protosappanin-type ones. Additionally, the vicinal diol in 3-benzylchroman-3,4-diol type homoisoflavonoids could be reduced to give 3-benzylchroman type compounds.

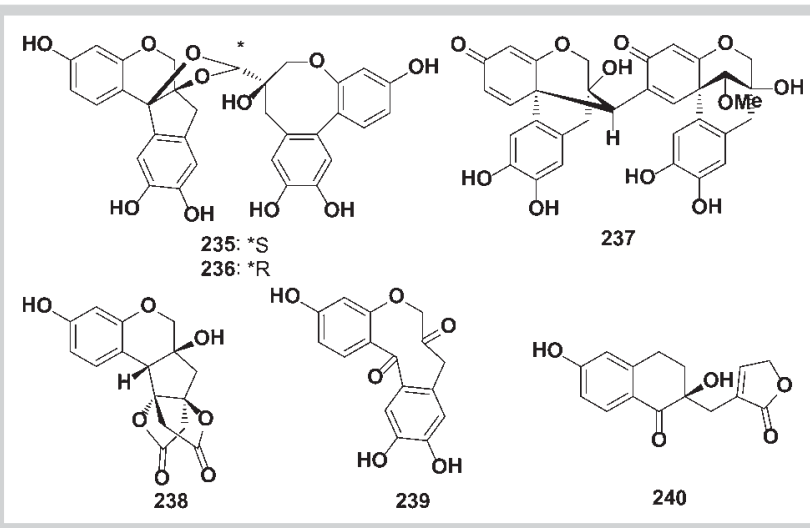

Fig. 5 Structures of miscellaneous homoisoflavonoids.

\section{Pharmacological Activities}

$\nabla$

Homoisoflavonoids have been reported to exert wide range of biological activities. These include: anti-microbial, anti-mutagenic, anti-oxidant, immunomodulatory, anti-diabetic, cytotoxic, antiangiogenetic, vasorelaxant, and anti-inflammatory effects. In addition, homoisoflavonoids were reported to inhibit protein tyrosine kinase and showed estrogenic and anti-estrogenic activities.

\section{Anti-microbial effects}

Homoisoflavonoids have shown inhibitory activities against various kinds of microorganisms. Reddy et al. isolated four homoisoflavonoids, 4-0-methylsappanol (8), brazilin (208), caeasalpin J (217), and protosappanin A (224) from Caesalpinia sappan and found that 4-O-methylsappanol possesses growth inhibitory activity against the fungus Beauveria bassiana, at a concentration of $100 \mu \mathrm{g} / \mathrm{mL}$ comparable to that of the standard drug dithane M-45 [84]. A homoisoflavonone, 3-(4'-methoxybenzyl)-7,8methylenedioxy-chroman-4-one (26), was isolated from Chlorophytum inornatum, which exhibited MIC ranging from 16$256 \mu \mathrm{g} / \mathrm{mL}$ against growth of four strains of fast-growing mycobacteria [53]. In search for EP inhibitors from natural products, Roy et al. found that bonducellin (157), a homoisoflavonoid isolated from $C$. digyna roots, showing a reduction of the MIC of ethidium bromide against Mycobacterium smegmatis mc $^{2} 155$ by eight fold to a concentration of $62.5 \mathrm{mg} / \mathrm{L}$, also showed significant EP inhibitory activity [28].

\section{Anti-mutagenic effects}

Mutagens are physical or chemical agents that change the genetic material [85]. Homoisoflavonoids have shown anti-mutagenic activities against several mutagens. Wall et al. isolated two homoisoflavonoids, intricatin (167) and intricatinol (161), from Hoffmannseggia intricata and found that both compounds are able to inhibit the mutagenicity of 2AN towards Salmonella typhimurium [75]. Intricatinol was found to be much more active than intricatin in the inhibition of the mutagenicity of AAF toward S. typhimurium and the inhibition of EMS toward S. typhimurium [75]. A mixture containing three homoisoflavonoids $(\mathbf{1 7 9}, \mathbf{1 8 4}$, and 185) from Muscari racemosum was shown to exert anti-mutagenic effects on four strains of $S$. typhimurium and the yeast strain Saccharomyces cerevisiae, and anti-clastogenic effect on Vicia sativa [86]. These results suggest that homoisoflavonoids could be included in the group of natural anti-mutagens of great 


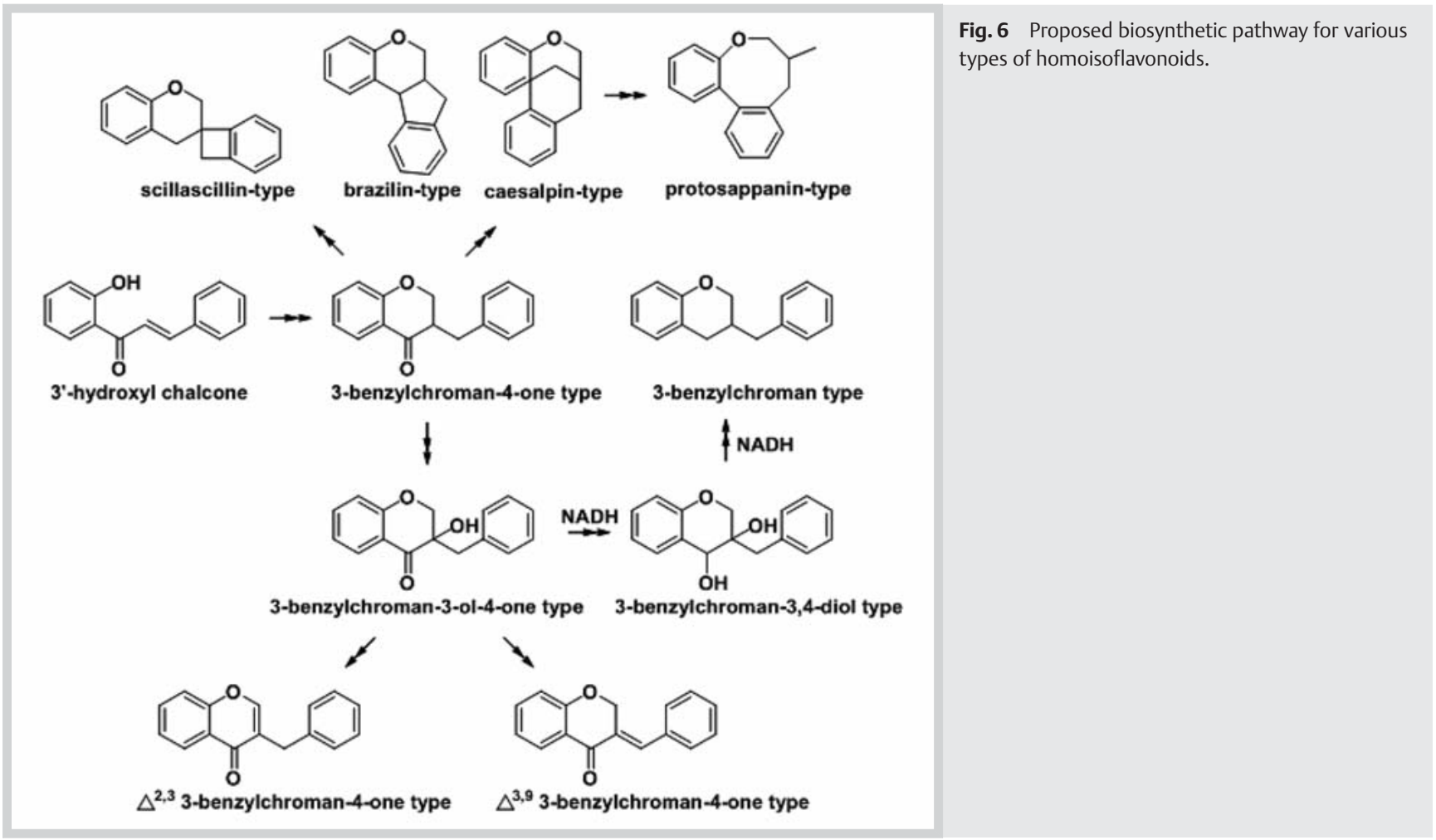

pharmacological importance and might be beneficial for the prevention of cancer.

\section{Anti-oxidant activity}

ROS actively participate in a diverse array of biological processes. Imbalance between production of ROS and anti-oxidant defenses causes oxidative stress, resulting in genomic instability and tissue damage [87]. Most polyphenols exhibit anti-oxidant properties, including homoisoflavonoids. Machala et al. isolated a series of homoisoflavonoids from the endemic tropical plant Dracaena cinnabari Balf., which showed potential activities to inhibit CYP1A enzymes and Fe-enhanced in vitro peroxidation of microsomal lipids in C57Bl/6 mouse liver [88]. Calvo reported the isolation of three homoisoflavanones, namely ledebourin A (106), ledebourin $B$ (107), and ledebourin C (108), from the bulbs of Ledebouria floribunda. Ledebourin $\mathrm{B}$ and ledebourin $\mathrm{C}$ exhibited potent antioxidant activity in the DPPH radical-scavenging compared to the positive controls, the well-known antioxidants BHT and BHA [3].

\section{Immunomodulation}

Brazilin (208), the main compound of Caesalpinia sappan, was reported to improve altered immune functions caused by halothane administration in mice [89]. Furthermore, brazilin decreased splenic cellularity and IL-2 production which had been augmented in mice treated with halothane $(21.5 \%$ in olive oil, $10 \mathrm{mmol} / \mathrm{kg}$ ) for 4 consecutive days, whereas the reduced expression of IL-2 receptors by concanavalin A was increased by brazilin treatment. These data indicate that brazilin affects the function of $\mathrm{T}$ cells and improves halothane-induced abnormal immune responses. Yang et al. reported that the intraperitoneal administration of brazilin for 5 consecutive days prevents the decrease of concanavalin A-induced proliferation of splenocytes and mixed lymphocyte reaction in low-dose streptozotocin-induced type I diabetic mice and increased IL-2 production without affecting suppressor cell activity. Expression of high affinity IL-2 receptors was also enhanced by brazilin. These results indicate that brazilin augments cellular immune responses, which are suppressed in the streptozotocin-induced type I diabetic mice, by increasing IL-2 production and responsiveness of immune cells to IL-2 [90].

\section{Anti-diabetic activities}

Homoisoflavonoids have shown significant activities in regulation of glucose uptake, hepatic glucose output, and adipocytes differentiation. Moon et al. found that brazilin (208) remarkably lowered non-fasting plasma glucose level without any changes in plasma insulin level and increased the rate of glucose oxidation and lipogenesis only in the presence of insulin. Activities of glucose-6 phosphate dehydrogenase and fatty acid synthase, involved in glucose oxidation and lipogenesis, respectively, were significantly increased. The results suggested that brazilin might exert hypoglycemic action in insulin resistance state by regulating the enzymatic reaction process involved in glucose metabolism [91]. Khil et al. reported that brazilin (208) increased $\left[\mathrm{H}^{3}\right] 2-$ deoxy-D-glucose uptake, which was blocked by phenylarsine oxide, the inhibitor of glucose transporters translocation, or wortmannin, the inhibitor of PI3-kinase. Western blot analysis with an anti-GLUT4 antibody revealed that brazilin increased the translocation of GLUT4 from intracellular pools to the plasma membrane. Brazilin, in combination with phorbol ester, showed an additive effect on glucose transport. The stimulating effect of phorbol ester on glucose transport was inhibited by staurosporine, but the effect of brazilin remained unchanged. The study suggested that brazilin may increase glucose transport by recruitment of GLUT4 from intracellular pools to the plasma membrane of adipocytes via the activation of PI3-kinase [92]. You et al. reported that brazilin (208) decreases blood glucose in diabetic animals, increases the production of F-2,6-BP in hepatocytes by elevating intracellular levels of F-6-P and H-6-P and also in- 
creases the activity of PFK-2 and pyruvate kinase in glucagontreated hepatocytes, which suggests that brazilin plays a role in hepatic glucose output by regulating gluconeogenesis and glycolysis in the liver [93]. Zhang et al. reported that the EtOAc-soluble fraction of a $90 \% \mathrm{MeOH}$ extract of the fibrous roots of Polygonatum odoratum was found to potentiate insulin-stimulated glucose uptake in differentiated 3 T3-L1 adipocytes. Further bioassay-guided fractionation yielded four homoisoflavonoids (54, $\mathbf{5 8}, \mathbf{1 6 9}$, and $\mathbf{1 8 0}$ ), which showed effects of sensitizing adipocytes for insulin in a cell-based glucose uptake assay using 3 T3-L1 adipocytes. The results indicated that homoisoflavonoids may be potential insulin sensitizers [33]. Liang et al. reported that brazilein (215), a natural, biologically active compound from Caesalpinia sappan, inhibited intracellular lipid accumulation during adipocyte differentiation in 3 T3-L1 cells and suppressed the induction of PPAR $\gamma$, the master regulator of adipogenesis, suggesting that brazilein possesses anti-obesity effects [18]. AMPK is a major cellular energy sensor and plays a central role in studies on diabetes. Guo et al. isolated six homoisoflavonoids from the rhizomes of Polygonatum odoratum Druce, and found that (3R)-5,7dihydroxyl-6-methyl-3-(4'-hydroxylbenzyl)-chroman-4-one

(47), (3R)-5,7-dihydroxyl-6,8-dimethyl-3-(4'-hydroxylbenzyl)chroman-4-one (52), and (3R)-5,7-dihydroxyl-6-methyl-8-methoxyl-3-(4'-hydroxylbenzyl)-chroman-4-one (61) significantly activated AMPK and acetyl-CoA carboxylase in rat liver epithelial IAR-20 cells [11].

\section{Cytotoxicity and anti-angiogenesis}

Homoisoflavonoids showed cytotoxicity against a number of cell lines from a wide range of tumors, mainly including breast cancer, lung cancer, and colon cancer. Guo et al. reported that pretreatment with brazilin (208) dose-dependently inhibited PDGF-stimulated VSMC proliferation and migration, which were associated with a cell-cycle arrest at G0/G1 phase, a reduction in the adhesion molecule expression and MMP-9 activation in VSMCs. Furthermore, the increase in PDGF receptor $\beta$, c-src, ERK1/2, and Akt phosphorylation induced by PDGF were suppressed by brazilin. Collectively, the study implicated that brazilin may be useful as an anti-proliferative agent for the treatment of vascular diseases [12]. Mutanyatta et al. isolated and structurally elucidated five homoisoflavonoids (40, 80, 94, 194, and 199) from Ledebouria graminifolia and submitted them to the US National Cancer Institute for investigation of in vitro primary cytotoxic and anti-proliferative activities using a panel of 60 different human tumor cell lines [59]. Compound $\mathbf{8 0}$ was noted to show some activity on MCF7 breast cancer line $\left(\mathrm{GI}_{50}=7 \mu \mathrm{g} / \mathrm{mL}, 50 \%\right.$ growth inhibition), while other compounds were inactive. Zhou et al. identified 13 homoisoflavonoids from the root tubers of Ophiopogon japonicus, including three compounds, 8-formylophiopogonanone B (60), 6-formylisoophiopogonone B (70), and 8-formyl-7-hydroxy-5,4'-dimethoxy-6-methylhomoisoflavone (95), and evaluated those for their cytotoxic activities against the human-lung-tumor A549 cell line. The study showed that four known compounds exhibited promising anti-proliferative activities [36]. Rafi et al. isolated and identified a structure specific homoisoflavone (53) from Vietnamese coriander (Polygonatum odoratum) root which induces $\mathrm{Bcl}-2$ phosphorylation, thereby causing mitotic arrest in breast cancer cells. Compound 53 induced Bcl-2 phosphorylation in breast tumor cells, caused G2/M cell cycle arrest, up regulated the expression of p21 and p53 proteins and decreased cell viability demonstrated by a clonogenic assay [26]. Dai et al. reported six homoisoflavonoids $(32,104$,
105, and 130-132) from the South African plant Drimia depressa Baker and discovered their anti-proliferative activity against the A2780 ovarian cancer, A2058 melanoma, and H522-T1 human non-small-cell lung cancer cells [7]. Nguyen et al. isolated a homoisoflavanone, disporopsin (37), from cytotoxic extracts of the roots of Disporopsis aspera (Asparagaceae). The homoisoflavanone was found to be cytotoxic against a series of human cancer cell lines (HCT15, T24S, MCF7, Bowes, A549, and K562) with IC 50 ranging from 15 to $200 \mu \mathrm{M}$ [94].

Anti-angiogenesis is a promising way for treatment of cancer [95]. Shim et al. isolated a homoisoflavanone, 7-dihydroxy-3(3-hydroxy-4-methoxybenzyl)-6-methoxychroman-4-one (78), from the bulb of Cremastra appendiculata (Orchidaceae) as a potent inhibitor of angiogenesis. It inhibited bFGF-induced in vitro angiogenesis and in vivo angiogenesis of the CAM of chick embryo without showing any toxicity [96].

\section{Anti-inflammatory activities}

Long-term inflammation has been considered as a cause of several diseases, such as type 2 diabetes, cardiovascular diseases and neuro-degenerative diseases [97-99], while overproduction of NO is responsible for inflammation [100]. Many studies have shown that homoisoflavonoids inhibit NO production in macrophage cells. Hung T. et al. isolated compounds 64, 69 and 98 from the roots of Ophiopogon japonicus (Asparagaceae) and discovered that these compounds suppressed IL-4-induced inflammatory chemokine eotaxin release in BEAS-2B cells [14]. Moreover, Li et al. who report the isolation of ophiopogonone E (151) and ophiopogonanone $\mathrm{H}$ (126) from the tuberous roots of Ophiopogon japonicus found that ophiopogonanone $\mathrm{H}$ is effective in the inhibition of NO production induced by lipopolysaccharide in the murine microglial cell line BV-2, with an $\mathrm{IC}_{50}$ value of $20.1 \mu \mathrm{M}$ [17]. Min et al. isolated thirteen phenolics from the heartwood of Caesalpinia sappan. Among them, protosappanin A (224) and 3-deoxysappanchalcone showed strong inhibitory activities toward the LPS-induced NO production in macrophage RAW264.7 cells, with $\mathrm{IC}_{50}$ values of 12.5 and $8.1 \mu \mathrm{M}$, respectively. In addition, these two compounds inhibited the induction of iNOS mRNA in dose-dependent manner, indicating that these compounds attenuated the synthesis of these transcripts at the transcriptional level [24].

\section{Protein tyrosine kinase inhibition}

PTKs play crucial roles in cell differentiation, proliferation, and apoptosis. More than $70 \%$ of the known oncogenes and proto-oncogenes involved in cancer code for PTKs [101]. Lin et al. identified hematoxylin (213), the major constituent of Haematoxylum campechianum, as one of the most remarkable c-Src inhibitors in an orthogonal compound-mixing library (32200 compounds) by using an ELISA-based automated HTS strategy [20]. Furthermore, hematoxylin was found to be an ATP competitive broad-spectrum PTK inhibitor in vitro, with $\mathrm{IC}_{50}$ values ranging from nanomolar to micromolar level, and the inhibition was associated with the PTK phosphorylation and subsequent downstream signaling pathways. Additionally, a series of hematoxylin analogues were isolated from $H$. campechianum with potent PTK inhibitory activity [20,21]. The structure-activity relationship assessment of the PTK inhibitory potency was in good agreement with the result of the concurrent molecular docking simulation. Hematoxylin and its natural analogues were substantially validated to serve as a new class of PTK inhibitors. 


\section{Other activities}

Hu et al. investigated the vasorelaxant activity of brazilin (208) in isolated rat aorta and human umbilical vein endothelial cells [102]. In isolated rat aorta, Caesalpinia sappan extract and brazilin relaxed phenylephrine-induced vasocontraction and increased cGMP content. Induction of vasorelaxation of brazilin was endothelium-dependent and could be markedly blocked by pretreatment with NOS inhibitor, L-NAME; L-NMMA and guanylyl cyclase inhibitor, methylene blue; ODQ and NO scavenger, hemoglobin. The increasing cGMP content induced by brazilin was also blocked by pretreatment with L-NAME, methylene blue, and the removal of extracellular $\mathrm{Ca}^{2+}$. In human umbilical vein endothelial cells, brazilin dose-dependently induced an increase in NO formation and NOS activity, which was greatly attenuated by either the removal of extracellular $\mathrm{Ca}^{2+}$ or the chelating of intracellular $\mathrm{Ca}^{2+}$ with BAPTA-AM. Moreover, brazilin dose-dependently induced the influx of extracellular $\mathrm{Ca}^{2+}$ in human umbilical vein endothelial cells. These results suggested that brazilin induces vasorelaxation by increasing intracellular $\mathrm{Ca}^{2+}$ concentration in endothelial cells of blood vessels and hence activating $\mathrm{Ca}^{2+} / \mathrm{calm}_{-}$ odulin-dependent NO synthesis, resulting in vasorelaxation.

Urbancikova et al. extracted a homoisoflavonoid-enriched fraction from Muscari racemosum and found estrogenic activity. The mixture enlarged the proliferation activity of MCF7 cells in a dose-dependent manner at concentrations up to $5 \mu \mathrm{g} / \mathrm{mL}$. A concentration of $5 \mu \mathrm{g} / \mathrm{mL}$ caused the highest increase of proliferation activity representing $181 \%$ of the control. Additionally, the extract exhibited a dose-dependent anti-estrogenic effect in the presence of estradiol in MCF7 cells [103]. Tsai et al. isolated eight homoisoflavonoids from the roots of Liriope platyphylla, and found that (3R)-3-(4'-hydroxybenzyl)-5,7-dihydroxylchroman4-one (30) and 3-(40-hydroxybenzylidene)-5,7-dihydroxychroman-4-one (117) exhibited the most potent estrogenic activity, and (3R)-3-(2',4'-dihydroxybenzyl)-5,7-dihydroxychroman-4one (37) and (3R)-3-(2',4'-dihydroxybenzyl)-5,7-dihydroxy-6methyl-chroman-4-one (51) showed the highest inhibitory activity in platelet aggregation assay [29].

\section{Conclusions}

$\nabla$

Homoisoflavonoids have received much attention in the literatures over the past 30 years. The structure diversity of homoisoflavonoids has attracted research interest of natural product chemists. Until now, 240 homoisoflavonoids have been isolated and identified, which could be classified into five structural categories, sappanin-type, scillascillin-type, brazilin-type, caesalpintype, and protosappanin-type. Homoisoflavonoids have become of interest in the research and development of natural bioactive compounds over the past decades. A broad range of activities have been reported, including anti-microbial effects, anti-mutagenic effects, anti-oxidant activities, immunomodulation, antidiabetic activities, cytotoxic and anti-angiogenic effects, and anti-inflammatory activities. However, most of the research involves in vitro studies; it is still a long way from drawing definite conclusions about the usefulness of homoisoflavonoids as drug candidates or lead compounds. More investigations on pharmacology and chemistry, as well as toxicological researches, should be done for better validation of the therapeutic potential of homoisoflavonoids.

\section{Acknowledgements}

$\nabla$

Financial support by the Research Fund of the University of Macau (SRG2013-00038-ICMS-QRCM and MYRG2014-00020ICMS-QRCM) and the Science and Technology Development Fund of Macau (120/2013/A3) are gratefully acknowledged.

\section{Conflict of Interest}

$\nabla$

The authors declare no conflict of interest.

\section{References}

1 Abegaz BM, Mutanyatta-Comar J, Nindi M. Naturally occurring homoisoflavonoids: Phytochemistry, biological activities and synthesis. Nat Prod Commun 2007; 2: 475-498

2 Ata A, Gale EM, Samarasekera R. Bioactive chemical constituents of Caesalpinia bonduc (Fabaceae). Phytochem Lett 2009; 2: 106-109

3 Calvo MI. Three new homoisoflavanones from the bulbs of Ledebouria floribunda. Fitoterapia 2009; 80: 394-398

4 Chen P, Yang JS. Flavonol galactoside caffeiate ester and homoisoflavones from Caesalpinia millettii HOOK. et ARN. Chem Pharm Bull 2007; 55: 655-657

5 Chen PY, Kuo YC, Chen CH, Kuo YH, Lee CK. Isolation and immunomodulatory effect of homoisoflavones and flavones from Agave sisalana Perrine ex Engelm. Molecules 2009; 14: 1789-1795

6 Cuong TD, Hung TM, Kim JC, Kim EH, Woo MH, Choi JS, Lee JH, Min BS. Phenolic compounds from Caesalpinia sappan heartwood and their anti-inflammatory activity. J Nat Prod 2012; 75: 2069-2075

7 Dai YM, Harinantenaina L, Brodie PJ, Goetz M, Shen YC, TenDyke K, Kingston DGI. Antiproliferative homoisoflavonoids and bufatrienolides from Urginea depressa. J Nat Prod 2013; 76: 865-872

8 Das B, Thirupathi P, Ravikanth B, Kumar RA, Sarma AVS, Basha SJ. Isolation, synthesis, and bioactivity of homoisoflavonoids from Caesalpinia pulcherrima. Chem Pharm Bull 2009; 57: 1139-1141

9 Duan CL, Kang ZY, Lin CR, Jiang Y, Liu JX, Tu PF. Two new homoisoflavonoids from the fibrous roots of Ophiopogon japonicus (Thunb.) KerGawl. J Asian Nat Prod Res 2009; 11: 876-879

10 Famuyiwa SO, Sichilongo KF, Yeboah SO, Abegaz BM. Homoisoflavonoids from the inter-bulb surfaces of Scilla nervosa subsp rigidifolia. Phytochem Lett 2012; 5: 591-595

11 Guo H, Zhao H, Kanno Y, Li W, Mu Y, Kuang X, Inouye Y, Koike K, Jiang H, Bai H. A dihydrochalcone and several homoisoflavonoids from Polygonatum odoratum are activators of adenosine monophosphate-activated protein kinase. Bioorg Med Chem Lett 2013; 23: 3137-3139

12 Guo J, Li L, Wu YJ, Yan Y, Xu XN, Wang SB, Yuan TY, Fang LH, Du GH. Inhibitory effects of brazilin on the vascular smooth muscle cell proliferation and migration induced by PDGF-BB. Am J Chin Med 2013; 41: 1283-1296

13 Gupta D, Bleakley B, Gupta RK. Bioassay guided isolation of antibacterial homoisoflavan from Dragonis blood resin (Dammul-akhwain). Nat Prod Rad 2009; 8: 494-497

14 Hung TM, Cao VT, Nguyen TD, Ryoo SW, Lee JH, Kim JC, Na M, Jung HJ, Bae $K$, Min BS. Homoisoflavonoid derivatives from the roots of Ophiopogon japonicus and their in vitro anti-inflammation activity. Bioorg Med Chem Lett 2010; 20: 2412-2416

15 Jeong HJ, Kim YM, Kim JH, Kim JY, Park JY, Park SJ, Ryu YB, Lee WS. Homoisoflavonoids from Caesalpinia sappan displaying viral neuraminidases inhibition. Biol Pharm Bull 2012; 35: 786-790

16 Koorbanally C, Sewjee S, Mulholland DA, Crouch NR, Dold A. Homoisoflavanones from Pseudoprospero firmifolium of the monotypic tribe Pseudoprospereae (Hyacinthaceae:Hyacinthoideae). Phytochemistry 2007; 68: 2753-2756

17 Li N, Zhang JY, Zeng KW, Zhang L, Che YY, Tu PF. Anti-inflammatory homoisoflavonoids from the tuberous roots of Ophiopogon japonicus. Fitoterapia 2012; 83: 1042-1045

18 Liang CH, Chan LP, Chou TH, Chiang FY, Yen CM, Chen PJ, Ding HY, Lin RJ. Brazilein from Caesalpinia sappan L. antioxidant inhibits adipocyte differentiation and induces apoptosis through caspase-3 activity and anthelmintic activities against Hymenolepis nana and Anisakis simplex. Evid Based Complement Alternat Med 2013; 2013: 864892 
19 Likhitwitayawuid K, Sawasdee K, Kirtikara K. Flavonoids and stilbenoids with COX-1 and COX-2 inhibitory activity from Dracaena loureiri. Planta Med 2002; 68: 841-843

20 Lin LG, Xie H, Li HL, Tong LJ, Tang CP, Ke CQ Liu QF, Lin LP, Geng MY, Jiang $H$, Zhao WM, Ding J, Ye Y. Naturally occurring homoisoflavonoids function as potent protein tyrosine kinase inhibitors by c-Src-based highthroughput screening. J Med Chem 2008; 51: 4419-4429

21 Lin LG, Xie H, Wang YT, Ding J, Ye Y. Chemical constituents from the heartwood of Haematoxylon campechianum as protein tyrosine kinase inhibitors. Chem Biodivers 2014; 11: 776-783

22 Liu J, Mei WL, Wu J, Zhao YX, Peng M, Dai HF. A new cytotoxic homoisoflavonoid from Dracaena cambodiana. J Asian Nat Prod Res 2009; 11: 192-195

23 Midiwo JO, Omoto FM, Yenesew A, Akala HM, Wangui J, Liyala P, Wasunna C, Waters NC. The first 9-hydroxyhomoisoflavanone, and antiplasmodial chalcones, from the aerial exudates of Polygonum senegalense. Arkivoc 2007; 9: 21-27

24 Min BS, Cuong TD, Hung TM, Min BK, Shin BS, Woo MH. Compounds from the heartwood of Caesalpinia sappan and their anti-inflammatory activity. Bioorg Med Chem Lett 2012; 22: 7436-7439

25 Nishida Y, Eto M, Miyashita H, Ikeda T, Yamaguchi K, Yoshimitsu H, Nohara T, Ono $M$. A new homostilbene and two new homoisoflavones from the bulbs of Scilla scilloides. Chem Pharm Bull 2008; 56: 10221025

26 Rafi MM, Vastano BC. Identification of a structure specific Bcl-2 phosphorylating homoisoflavone molecule from Vietnamese coriander (Polygonatum odoratum) that induces apoptosis and G2/M cell cycle arrest in breast cancer cell lines. Food Chem 2007; 104: 332-340

27 Roy SK, Agrahari UC, Gautam R, Srivastava A, Jachak SM. Isointricatinol, a new antioxidant homoisoflavonoid from the roots of Caesalpinia digyna Rottler. Nat Prod Res 2012; 26: 690-695

28 Roy SK, Kumari N, Gupta S, Pahwa S, Nandanwar H, Jachak SM. 7-Hydroxy-(E)-3-phenylmethylene-chroman-4-one analogues as efflux pump inhibitors against Mycobacterium smegmatis mc(2) 155. Eur J Med Chem 2013; 66: 499-507

29 Tsai YC, Chiang SY, El-Shazly M, Wu CC, Beerhues L, Lai WC, Wu SF, Yen $M H, W u$ YC, Chang FR. The oestrogenic and anti-platelet activities of dihydrobenzofuroisocoumarins and homoisoflavonoids from Liriope platyphylla roots. Food Chem 2013; 140: 305-314

30 Waller CP, Thumser AE, Langat MK, Crouch NR, Mulholland DA. COX-2 inhibitory activity of homoisoflavanones and xanthones from the bulbs of the Southern African Ledebouria socialis and Ledebouria ovatifolia (Hyacinthaceae: Hyacinthoideae). Phytochemistry 2013; 95: 284-290

31 Wang Z, Sun JB, Qu W, Guan FQ Li LZ, Liang JY. Caesappin A and B, two novel protosappanins from Caesalpinia sappan L. Fitoterapia 2014; 92 : 280-284

32 Yan J, Sun LR, Zhou ZY, Chen YC, Zhang WM, Dai HF, Tan JW. Homoisoflavonoids from the medicinal plant Portulaca oleracea. Phytochemistry 2012; 80: 37-41

33 Zhang H, Yang F, Qi J, Song XC, Hu ZF, Zhu DN, Yu BY. Homoisoflavonoids from the fibrous roots of Polygonatum odoratum with glucose uptakestimulatory activity in 3 T3-L1 adipocytes. J Nat Prod 2010; 73: 548552

34 Zhao MB, Li J, Shi SP, Cai CQ Tu PF, Tang L, Zeng KW, Jiang Y. Two new phenolic compounds from the heartwood of Caesalpinia sappan L. Molecules 2013; 19: 1-8

35 Zhao $H$, Wang X, Li W, Koike K, Bai $H$. A new minor homoisoflavonoid from Caesalpinia sappan. Nat Prod Res 2014; 28: 102-105

36 Zhou CX, Zou L, Mo JX, Wang XY, Yang B, He OJ, Gan LS. Homoisoflavonoids from Ophiopogon japonicus. Helv Chim Acta 2013; 96: 13971405

37 Anh NTH, Van Sung T, Porzel A, Franke K, Wessjohann LA. Homoisoflavonoids from Ophiopogon japonicus Ker-Gawler. Phytochemistry 2003; 62: $1153-1158$

38 Asano T, Murayama T, Hirai Y, Shoji J. Comparative studies on the constituents of Ophiopogonis tuber and its congeners. VII. Studies on the homoisoflavonoids of the subterranean part of Ophiopogon japonicus Ker-Gawler cv. Nanus. Chem Pharm Bull 1993; 41: 391-393

39 Chang JM, Shen CC, Huang YL, Chien MY, Ou JC, Shieh BJ, Chen CC. Five new homoisoflavonoids from the tuber of Ophiopogon japonicus. J Nat Prod 2002; 65: 1731-1733

40 Kaneda N, Nakanishi H, Kuraishi T, Katori T. Studies on the components of Ophiopogon roots (China). Yakugaku Zasshi 1983; 103: 1133-1139
41 Tada A, Kasai R, Saitoh T, Shoji J. Studies on the constituents of Ophiopogonis tuber: structures of homoisoflavonoids. Chem Pharm Bull 1980; 28: 2039-2044

42 Watanabe Y, Sanada S, Ida Y, Shoji J. Comparative studies on the constituents of Ophiopogonis tuber and its congeners. IV. Studies on the homoisoflavonoids of the Subterranean part of Ophiopogon ohwii Okuyama and Ophiopogon jaburan (Kunth) Lodd. Chem Pharm Bull 1985; 33: 5358-5363

43 Nagai M, Nagumo S. Protosappanin-C from sappan lignum and absolute configuration of protosappanins. Chem Pharm Bull 1987; 35: 3002 3005

44 Nagai M, Nagumo S. Protosappanin-E-1 and protosappanin-E-2, stereoisomeric dibenzoxocins combined with brazilin from sappan lignum. Chem Pharm Bull 1990; 38: 1490-1494

45 Namikoshi M, Nakata H, Nuno M, Ozawa T, Saitoh T. Homoisoflavonoids and related-compounds. III. Phenolic constituents of Caesalpinia japonica Sieb et Zucc. Chem Pharm Bull 1987; 35: 3568-3575

46 Namikoshi M, Nakata H, Saitoh T. Homoisoflavonoids and related-compounds. V. A novel dibenzoxocin derivative from Caesalpinia sappan L. Chem Pharm Bull 1987; 35: 3615-3619

47 Namikoshi M, Nakata H, Saitoh T. Homoisoflavonoids and related compounds. I. Homoisoflavonoids from Caesalpinia sappan. Phytochemistry $1987 ; 26: 1831-1833$

48 Namikoshi M, Nakata H, Yamada H, Nagai M, Saitoh T. Homoisoflavonoids and related compounds. II. Isolation and absolute configurations of 3, 4-dihydroxylated homoisoflavans and brazilins from Caesalpinia sappan L. Chem Pharm Bull 1987; 35: 2761-2773

49 Namikoshi M, Saitoh T. Homoisoflavonoids and related compounds. IV. Absolute configurations of homoisoflavonoids from Caesalpinia sappan L. Chem Pharm Bull 1987; 35: 3597-3602

50 Saitoh T, Sakashita S, Nakata H, Shimokawa T, Kinjo J, Yamahara J, Yamasaki M, Nohara T. 3-Benzylchroman derivatives related to brazilin from sappan lignum. Chem Pharm Bull 1986; 34: 2506-2511

51 Shimokawa T, Kinjo J, Yamahara J, Yamasaki M, Nohara T. 2 novel aromatic compounds from Caesalpinia sappan. Chem Pharm Bull 1985; 33: 3545-3547

52 Yang BO, Ke CQ He ZS, Yang YP, Ye Y. Brazilide A, a novel lactone with an unprecedented skeleton from Caesalpinia sappan. Tetrahedron Lett 2002: 43: 1731-1733

53 O'Donnell G, Bucar F, Gibbons S. Phytochemistry and antimycobacterial activity of Chlorophytum inornatum. Phytochemistry 2006; 67: 178182

54 Jain SC, Sharma SK, Kumar R, Rajwanshi VK, Babu BR. A homoisoflavanone from Pterocarpus marsupium. Phytochemistry 1997; 44: 765766

55 Silayo A, Ngadjui BT, Abegaz BM. Homoisoflavonoids and stilbenes from the bulbs of Scilla nervosa subsp rigidifolia. Phytochemistry 1999; 52: 947-955

56 Koorbanally C, Mulholland DA, Crouch NR. A novel homoisoflavonoid from Drimia delagoensis (Urgineoideae: Hyacinthaceae). Biochem Syst Ecol 2005; 33: 743-748

57 Adinolfi M, Barone G, Belardini M, Lanzetta R, Laonigro G, Parrilli M. Homoisoflavanones from Muscari comosum bulbs. Phytochemistry 1985; 24: 2423-2426

58 Corsaro MM, Lanzetta R, Mancino A, Parrilli M. Homoisoflavanones from Chionodoxa luciliae. Phytochemistry 1992; 31: 1395-1397

59 Mutanyatta J, Matapa BG, Shushu DD, Abegaz BM. Homoisoflavonoids and xanthones from the tubers of wild and in vitro regenerated Ledebouria graminifolia and cytotoxic activities of some of the homoisoflavonoids. Phytochemistry 2003; 62: 797-804

60 Heller W, Andermatt P, Schaad WA, Tamm C. [Homoisoflavonones. IV. New constituents of the eucomin series of Eucomis bicolor (author's transl)]. Helv Chim Acta 1976; 59: 2048-2058

61 Bangani V, Crouch NR, Mulholland DA. Homoisoflavanones and stilbenoids from Scilla nervosa. Phytochemistry 1999; 51: 947-951

62 Adinolfi M, Corsaro MM, Lanzetta R, Laonigro G, Mangoni L, Parrilli M. 10 homoisoflavanones from 2 Muscari species. Phytochemistry 1987; 26: $285-290$

63 Delazar A, Nazemiyeh H, Afshar J. Identification of a new homoisoflavonone from Bellevalia longistyla. Ulumi Deroei 2002; 1: 33-38

64 Adinolfi M, Aquila T, Barone G, Lanzetta R, Parrilli M. Homoisoflavanones from Bellevalia romana. Phytochemistry 1989; 28: 3244-3246

65 Rafi MM, Vastano BC, Ho CT, Rosen RT. Novel compound isolated from Polygonum odoratum induces Bcl-2 phosphorylation and apoptosis in cancer cell tines. Faseb J 2002; 16: A743-A743 
66 Crouch NR, Bangani V, Mulholland DA. Homoisoflavanones from three South African Scilla species. Phytochemistry 1999; 51: 943-946

67 Amschler G, Frahm AW, Hatzelmann A, Kilian U, MullerDoblies D, MullerDoblies $U$. Constituents of Veltheimia viridifolia. I. Homoisoflavanones of the bulbs. Planta Med 1996; 62: 534-539

68 Koorbanally NA, Crouch NR, Harilal A, Pillay B, Mulholland DA. Coincident isolation of a novel homoisoflavonoid from Resnova humifusa and Eucomis montana. Biochem Syst Ecol 2006; 34: 114-118

69 Tang YP, Yu B, Hu J, Wu T, Hui HZ. Three new homoisoflavanone glycosides from the bulbs of Ornithogalum caudatum. J Nat Prod 2002; 65: 218-220

70 du Toit K, Elgorashi EE, Malan SF, Drewes SE, van Staden J, Crouch NR, Mulholland DA. Anti-inflammatory activity and QSAR studies of compounds isolated from Hyacinthaceae species and Tachiadenus longiflorus Griseb. (Gentianaceae). Bioorg Med Chem 2005; 13: 2561-2568

71 Hernandez JC, Leon F, Estevez F, Quintana J, Bermejo J. A homo-isoflavonoid and a cytotoxic saponin from Dracaena draco. Chem Biodivers 2006; 3: 62-68

72 Kumar R, Ilyas M, Parveen M, Shafiullah. A new chromone from Cassia nodosa. J Asian Nat Prod Res 2006; 8: 595-598

73 Srinivas KV, Koteswara Rao Y, Mahender I, Das B, Rama Krishna KV, Hara Kishore K, Murty US. Flavanoids from Caesalpinia pulcherrima. Phytochemistry 2003; 63: 789-793

74 Purushothaman KK, Kalyani K, Subramaniam K, Shanmughanathan SP. Structure of Bonducellin - a new homoisoflavone from Caesalpinia bonducella. Indian J Chem B 1982; 21: 383

75 Wall ME, Wani MC, Manikumar G, Taylor H, Mcgivney R. Plant antimutagens. 6. Intricatin and intricatinol, new antimutagenic homoisoflavonoids from Hoffmanosseggia intricata. J Nat Prod 1989; 52: 774-778

76 Mcpherson DD, Cordell GA, Soejarto DD, Pezzuto JM, Fong HHS. Peltogynoids and homoisoflavonoids from Caesalpinia pulcherrima. Phytochemistry 1983; 22: 2835-2838

77 Finckh RE, Tamm C. The homo-isoflavones. 3. Isolation and structure of punctatin, 3, 9-dihydro-punctatin, 4'-o-methyl-3, 9-dihydro-punctatin, 4'-demethyl-eucomin and 4'-demethyl-5-o-methyl-3, 9-dihydroeucomin. Experientia 1970; 26: 472-473

78 Masterova I, Suchy V, Uhrin D, Ubik K, Grancaiova Z, Bobovnicky B. Homoisoflavanones and other constituents from Muscari racemosum. Phytochemistry 1991; 30: 713-714

79 Barone G, Corsaro MM, Lanzetta R, Parrilli M. Homoisoflavanones from Muscari neglectum. Phytochemistry 1988; 27: 921-923

80 Kouno I, Komori T, Kawasaki T. Zur Struktur der neuen Typen HomoIsoflavanone aus Bulben von Scilla scilloides Druce. Tetrahedron Lett 1973; 14: 4569-4572

81 Masuda H, Ohtani K, Mizutani K, Ogawa S, Kasai R, Tanaka O. Chemical study on Haematoxylon campechianum - a sweet principle and new dibenz[b,d]oxocin derivatives. Chem Pharm Bull 1991; 39: 1382-1384

82 Meksuriyen D, Cordell GA, Ruangrungsi N, Tantivatana P. Traditional medicinal plants of Thailand, IX. 10-Hydroxy-11-methoxydracaenone and 7, 10-dihydroxy-11-methoxydracaenone from Dracaena loureiri. J Nat Prod 1987; 50: 1118-1125

83 Nguyen MT, Awale S, Tezuka Y, Tran QL, Kadota S. Neosppanone A, a xanthine oxidase $(\mathrm{XO})$ inhibitory dimeric methanodibenzoxocinone with a new carbon skeleton from Caesalpinia sappan. Tetrahedron Lett 2004; 45: 8519-8522
84 Reddy VLN, Ravikanth V, Lakshmi VVNSJ, Murty US, Venkateswarlu Y. Inhibitory activity of homoisoflavonoids from Caesalpinia sappan against Beauveria bassiana. Fitoterapia 2003; 74: 600-602

85 Benigni $R$, Bossa C. Alternative strategies for carcinogenicity assessment: an efficient and simplified approach based on in vitro mutagenicity and cell transformation assays. Mutagenesis 2011; 26: 455-460

86 Miadokova E, Masterova I, Vlckova V, Duhova V, Toth J. Antimutagenic potential of homoisoflavonoids from Muscari racemosum. J Ethnopharmacol 2002; 81: 381-386

87 Finkel T. Oxidant signals and oxidative stress. Curr Opin Cell Biol 2003; 15: $247-254$

88 Machala M, Kubinova R, Horavova P, Suchy V. Chemoprotective potentials of homoisoflavonoids and chalcones of Dracaena cinnabari: modulations of drug-metabolizing enzymes and antioxidant activity. Phytother Res 2001; 15: 114-118

89 Choi SY, Yang KM, Jeon SD, Kim JH, Khil LY, Chang TS, Moon CK. Brazilin modulates immune function mainly by augmenting $\mathrm{T}$ cell activity in halothane administered mice. Planta Med 1997; 63: 405-408

90 Yang KM, Jeon SD, So DS, Moon CK. Brazilin augments cellular immunity in multiple low dose streptozotocin (MLD-STZ) induced type I diabetic mice. Arch Pharm Res 2000; 23: 626-632

91 Moon CK, Lee SH, Lee MO, Kim SG. Effects of brazilin on glucose-oxidation, lipogenesis and therein involved enzymes in adipose tissues from diabetic KK-Mice. Life Sci 1993; 53: 1291-1297

92 Khil LY, Han SS, Kim SG, Chang TS, Jeon SD, So DS, Moon CK. Effects of Brazilin on GLUT4 recruitment in isolated rat epididymal adipocytes. Biochem Pharmacol 1999; 58: 1705-1712

93 You EJ, Khil LY, Kwak WJ, Won HS, Chae SH, Lee BH, Moon CK. Effects of brazilin on the production of fructose-2, 6-bisphosphate in rat hepatocytes. J Ethnopharmacol 2005; 102: 53-57

94 Nguyen AT, Fontaine J, Malonne H, Duez P. Homoisoflavanones from Disporopsis aspera. Phytochemistry 2006; 67: 2159-2163

95 Shojaei F. Anti-angiogenesis therapy in cancer: current challenges and future perspectives. Cancer Lett 2012; 320: 130-137

96 Shim JS, Kim JH, Lee JY, Kim SN, Kwon HJ. Anti-angiogenic activity of a homoisoflavanone from Cremastra appendiculata. Planta Med 2004; 70: $171-173$

97 Donath MY, Shoelson SE. Type 2 diabetes as an inflammatory disease. Nat Rev Immunol 2011; 11: 98-107

98 Willerson JT, Ridker PM. Inflammation as a cardiovascular risk factor Circulation 2004; 109: 2-10

99 Amor S, Puentes F, Baker D, van der Valk P. Inflammation in neurodegenerative diseases. Immunology 2010; 129: 154-169

100 Korhonen R, Lahti A, Kankaanranta H, Moilanen E. Nitric oxide production and signaling in inflammation. Curr Drug Targets 2005; 4: 471-479

101 Baselga J. Targeting tyrosine kinases in cancer: the second wave. Science 2006; 312: 1175-1178

$102 \mathrm{Hu}$ CM, Kang JJ, Lee CC, Li CH, Liao JW, Cheng YW. Induction of vasorelaxation through activation of nitric oxide synthase in endothelial cells by brazilin. Eur J Pharmacol 2003; 468: 37-45

103 Urbancikova M, Masterova I, Toth J. Estrogenic/antiestrogenic activity of homoisoflavonoids from bulbs of Muscari racemosum (L.) Miller. Fitoterapia 2002; 73: 724-726 